\title{
The first record of ultramafic cumulates from the Mt. Kalnik ophiolite mélange in the SW part of the Zagorje-Mid-Transdanubian Zone (NW Croatia): mineralogy, petrology, geochemistry and tectono-magmatic affinity
}

\author{
Damir Slovenec ${ }^{1}$ and Branimir Šegvić ${ }^{2}$ \\ ${ }^{1}$ Croatian Geological Survey, Sachsova 2, 10000 Zagreb, Croatia (corresponding author; e-mail: damir.slovenec@hgi-cgs.hr) \\ ${ }^{2}$ Texas Tech University, Department of Geosciences, 1200 Memorial Circle, Lubbock 79409 TX, USA (e-mail: branimir.segvic@ttu.edu)
}

doi: $10.4154 / g c .2018 .17$

Article history:

Manuscript received June 19, 2018

Revised manuscript accepted September 07, 2018

Available online October 17, 2018

\begin{abstract}
Ultramafic cumulate rocks represent the rarest allochthonous fragments of the Mesozoic oceanic lithosphere observed today in the Upper Jurassic to Lower Cretaceous mélange of Mt. Kalnik, located in the SW part of the Zagorje-Mid-Transdanubian Zone (ZMTDZ). Poikilitic heteroadcumulate ultramafic rocks of Mt. Kalnik are represented by amphibole Iherzolites/harzburgites and plagioclase Iherzolites. Both were formed by in-situ processes within a magma chamber following the general crystallization sequence of: Al-chromite $\rightarrow$ Mg-rich olivine $\rightarrow$ enstatite \pm augite $\rightarrow$ Ca-amphibole (pargasite \pm edenite \pm magnesiohornblende) $\rightarrow$ Ca-plagioclase $\left(A n_{82.6-87.4}\right)$. Cumulate minerals are spinel and olivine as well as orthopyroxene and clinopyroxene which are usually enclosed in intercumulate phases such as amphibole and/or plagioclase that render an interstitial mesostasis. Rocks' textural characteristics, mineral crystallization order and their phase chemistry are all suggestive of low-pressure sub-solidus crystallization in an open system. The low Ti content in augite and scant HFSE abundances suggest the studied rocks may have formed from a depleted mantle source. In addition to the medium to high degree of partial melting of the source, the parental process that gave rise to the Mt. Kalnik ultramafic cumulates also included a low degree of fractional crystallization. The segregation of oxidized Al-chromite and oikocrysts of pargasite and edenite in an early crystallization stage illustrates the formation of a cumulate sequence from volatile-rich magmas. These magmas usually have a high oxidation potential and are exclusively found in intra-oceanic subduction zones, predominantly in island arcs. The overall whole-rock geochemistry [e.g. $(\mathrm{Nb} / \mathrm{La})_{n}=0.25-0.34 ;(\mathrm{Ti} / \mathrm{Gd})_{n}=0.49-0.89$; $\left.(\mathrm{Th} / \mathrm{Nb})_{\mathrm{n}}=5.29-8.63 ;(\mathrm{La} / \mathrm{Lu})_{\mathrm{cn}}=0.57-0.68\right]$ together with a record of Ca-rich plagioclase (up to $\left.A n_{87.4}\right)$ and low Ti clinopyroxene $(\leq 0.54 \mathrm{wt} \%$ ) corroborate the supra-subduction tholeiitic nature of the magma source. Ultramafic cumulates from the ophiolitic mélange of Mts. Kalnik and Medvednica show common genetic features and geotectonic provenance. Comparison with analogous ultramafic lithotypes of the north-eastern segment of the ZMTDZ (the Szarvaskö Complex, Hungary), the ultramafic cumulates of Mts. Kalnik and Medvednica portray some subtle differences that may indicate their distinctive geotectonic provenance. Mts. Kalnik and Medvednica ultramafic cumulates represent the vestiges of a single Upper Jurassic intra-oceanic arc system formed in the western branch of the Meliata-Maliak segment of the Neotethyan oceanic realm.
\end{abstract}

Keywords: ultramafic cumulates, island arc, ophiolite mélange, Zagorje-Mid-Transdanubian Zone, Mt. Kalnik, Croatia
SHERVAIS, 2001; PEARCE et al., 2003; PEARCE, 2008; BORTOLOTTI et al., 2013; SACCANI \& TASSINARI, 2015). Ultramafic rocks affiliated to ophiolite are commonly found in the Dinarides and Carpathians as a component of ophiolite complexes (e.g. BALLA, 1984; HOVORKA et al., 1985; PAMIĆ \& DESMONS, 1989; LUGOVIĆ et al., 1991; MAJER, 1993; IVAN, 2002; HOECK et al., 2006). As integral parts of an ophiolite, ultramafic cumulates emerge as slices of oceanic plates that are now observed obducted and emplaced onto passive continental plate margins. More typically, these cumulates occur in the form of fragmented allochthonous bodies (olistoliths), embedded in the chaotic rock mixture usually referred to as an ophiolitic mélange (e.g. WAKABAYASHI \& DILEK, 2003; FESTA et al., 2010). Ophiolite mélange represents a disordered tectono-sedimentary complex initially formed by tectonically activated sedimentary processes in the deep oceanic trench (accretionary wedge) developed in a forearc region in front of the leading edge of the overriding plate (RAYMOND, 1984; FESTA et al., 2010). \& NESBITT, 1978; SAUNDERS et al., 1980; SERRI, 1981; 
In NW Croatia the outcrops of ultramafite cumulate rocks are scarce and are limited to fragmented allochthonous blocks recovered from the mélange of Mts. Medvednica (SLOVENEC \& LUGOVIĆ, 2000; LUGOVIĆ et al., 2007) and Kalnik (Fig. la-b and 2). These blocks contribute to the commonly named "block-in-matrix" mélange fabric, which is characteristic for dismembered ophiolitic mélanges (LUGOVIĆ et al., 2007; SLOVENEC et al., 2011). The Mt. Kalnik mélange defines a single tectonostratigraphic unit of the larger Kalnik Unit (HAAS et al., 2000; Fig. 1b). The Kalnik Unit consists of the lithological remnants of a discrete Mesozoic (Triassic-Jurassic) oceanic domain that connects the Dinaric-Vardar ophiolites (e.g. LUGOVIĆ et al., 1991; PAMIĆ, 1997; PAMIĆ et al., 2002, SCHMID et al., 2008 and references therein), located to the southwest, with ophiolites exposed to the northeast in NE Hungary (e.g. BALLA et al., 1983, BALLA, 1984; DOWNES et al., 1990; HARANGI et al., 1996; AIGNER-TORRES \& KOLLER, 1999; HASS \& KOVÁCS, 2001; KISS et al., 2012 and references therein; SD, Bü-Fig. 1a) and SE Slovakia (e.g. HOVORKA et al., 1985; IVAN, 2002; FARYAD et al., 2005 and references therein; JK - Fig. 1a). The mountains of Kalnik and Medvednica, along with Ivanščica and Samoborska Gora, are located at the south-western tip of the SW-NE trending Zagorje-Mid-Transdanubian shear Zone (ZMTDZ; PAMIĆ \& TOMLJENOVIĆ, 1998), which represents a triple junction zone between the South-eastern Alps, Tiszia continental block and the Internal Dinarides. The Zone lies in the southern part of the Alcapa (Alpine-Carpathian-Pannonian) block of the Intra-Carpathian Area in the sense of HARANGI et al. (1996) (Fig. 1a-b). All the aforementioned Croatian inselbergs are composed of preNeogene heterogeneous tectonostratigraphic and tectonometamorphic units of superimposed Dinaric and Alpine affiliations (e.g. PAMIĆ \& TOMLJENOVIĆ, 1998; TARI \& PAMIĆ, 1998; HAAS et al., 2000; HAAS \& KOVÁCS, 2001; PAMIĆ, 2002). Finally, based on the similar tectonostratigraphic evolution, the ZMTDZ has been considered (after SCHMID et al., 2008) as an integral part of the Western Vardar Ophiolite Unit where it defines its north-westernmost segment.

The goal of this research is to present for the first time the mineralogical, petrological and geochemical characteristics of cumulate ultramafic rocks from the ophiolitic mélange of Mt. Kalnik and to infer their petrogenesis by discussing a plausible geotectonic setting of their formation. In the future, this study will add to the existing knowledge on the geodynamic evolution of the oceanic lithosphere of the Dinaridic Tethys during Mesozoic time by correlating our findings with analogous rocks from the neighbouring ophiolitic complexes or mélanges from the ZMTDZ.

\section{GEOLOGY OF MT. KALNIK}

A simplified geological map and stratigraphic column of Mt. Kalnik is shown in Figure 2. Its surface geology comprises Neogene clastic rocks and parts of the heterogeneous ophiolitic mélange. The northern part of the Mt. Kalnik ophiolite mélange is thrust onto the Neogene-Pleistocene sedimentary succession (ŠIMUNIĆ et al., 1982). All other contacts of the ophiolite mélange exhibit a tectonic-erosional unconformity against the youngest Neogene and Pleistocene sedimentary rocks (Fig. 2). The central ridge of Mt. Kalnik is composed of Palaeocene carbonate breccia thrust over Neogene sedimentary rocks (ŠIMUNIĆ et al., 1981). The common constituents of the breccia are fragments of Triassic algal and stromatolithic limestone and dolomite, as well as Jurassic and Upper Cretaceous limestone. Several individual tectonic slices of Early Cretaceous(?) highly serpentinized mantle peridotites of island arc (IA) affinity, several hundred metres in diameter were exhumed along the mountain ridge tectonic zone (POLJAK, 1942; ŠIMUNIĆ et al., 1981), accompanied by a composite slice of serpentinized lherzolites (LUGOVIĆ et al., 2007) that are underlain by the mass of orthoamphibolites (ŠEGVIĆ et al., 2016). Amphibolite occurs in the form of hectometre-sized blocks placed within the ophiolitic mélange that is tectonically inserted in the Palaeogene sedimentary succession. Geochemical and petrological characteristics of mantle peridotites and amphibolites indicate a common tectono-metamorphic history. The mélange is predominantly composed of homogenous metre-to-hectometre-kilometre-sized ophiolitic blocks (mafic extrusives, subordinate gabbros), showing various geochemical signatures (E-, T-, N-MORB, IA) consistent with their distinct geotectonic formation setting during an age span from the Ladinian to the Bajocian (oceanic setting), and the Bathonian to the Late Oxfordian (suprasubduction setting; CRNKOVIĆ et al., 1974; VRKLJAN, 1989; PAMIĆ, 1997; VRKLJAN \& GARAŠIĆ, 2004; SLOVENEC et al., 2011; LUGOVIĆ et al., 2015). However, some gabbroic blocks that appear as fault-bounded tectonic inclusions that were embedded in the mélange during ophiolite emplacement have been proved to represent evidence of back-arc Cretaceous magmatism (LUGOVIĆ et al., 2015). Two allochthonous and homogenous metre-sized blocks of ultramafic cumulates, that outcrop only rarely, are investigated in detail in this study. They have been recovered in the SE part of the Mt. Kalnik mélange in Kamešnica creek, about $1 \mathrm{~km}$ north of the central ridge of Mt. Kalnik (Fig. 2). In addition to ophiolitic blocks, mélange is also composed of the metre-to-hectometre-sized olistoliths of sedimentary rocks (greywackes, minor shales, Middle Triassic and Jurassic cherts, and scarce Triassic limestones), along with blocks of non-ophiolite (intracontinental rift) originated alkali basalts (e.g. ŠIMUNIĆ et al., 1982; SLOVENEC et al., 2011; Fig. 2). The blocks of Mesozoic rocks are embedded in a predominantly sheared continent-derived pelitic to silty matrix (Fig. 2). Based on matrix palynomorph assemblages, the accretionary age of the Kalnik Unit, i.e. ophiolite mélange is defined as Early Callovian to Late Valangian (BABIĆ et al., 2002). This time interval represents a period of accumulation of lithostratigraphically diverse material in an intra-oceanic trench (SLOVENEC et al., 2011). Following the accretion, these rocks underwent emplacement onto the eastern continental margins of the Adria plate in Aptian to post-Palaeocene time (PAMIĆ \& TOMLJENOVIĆ, 1998; PAMIĆ, 2002). There are arguments suggesting that the ZMTDZ was displaced by translation and rotation along the Zagreb-Zemplin lineament in a NE direction, finally reaching its present position during the Middle Miocene (PAMIĆ, 1997; TOMLJENOVIĆ et al., 2008; Fig. 1a-b).

\section{ANALYTICAL TECHNIQUES}

Twenty thin-sections of representative rock samples were analysed using an Olympus BH-2 polarization microscope installed at the Croatian Geological Survey (Zagreb, Croatia). The chemical composition of mineral phases from three samples were analysed at the Institute of Geosciences (University of Heidelberg, Germany) using a CAMECA SX51 electron microprobe equipped with five wavelength-dispersive spectrometers. The operating parameters included $15 \mathrm{kV}$ accelerating voltage, $20 \mathrm{nA}$ beam current, and $\sim 1 \mu \mathrm{m}$ beam size ( $10 \mu \mathrm{m}$ for feldspars). Counting times of $20 \mathrm{~s}$ on peak and $10 \mathrm{~s}$ on background on both sides of the peak were used for all elements. Limits of detection (LOD) were 


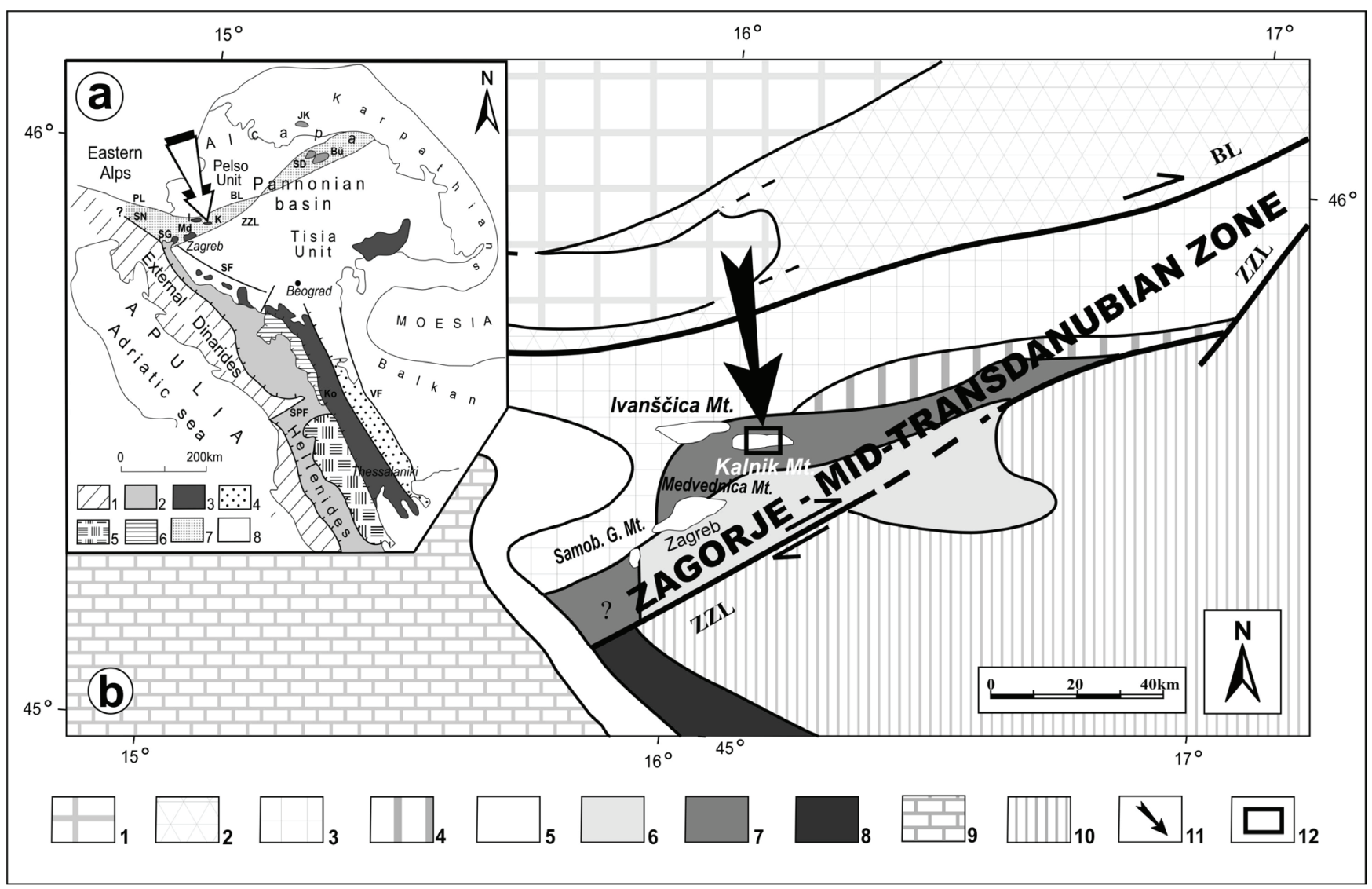

Figure 1. (a) Geotectonic sketch map of the Alps, Dinarides and Hellenides showing the position of the Zagorje-Mid-Transdsnubian Zone (after PAMIĆ, 2000). Legend: 1-External units (External Dinarides and Alps); 2-Internal units [Passive continental margin, Central Dinaride Ophiolite Belt (CDOB), Mirdita Zone]; 3-Periadriatic-Sava-Vardar Zone including the Inner Dinaric Ophiolite Belt (IDOB); 4-Serbo-Macedonian Massif; 5-Pelagonides; 6-Golija Zone; 7-Zagorje-Mid-Transdanubian Zone; 8-Panonian Basin. Faults: BL-Balaton; PL-Periadriatic; SF-Sava; SPF-Scutari-Peć; SN-Sava Nape;VF-Vardar; ZZL-Zagreb-Zemplin. Mountains: I-Ivanščica; K-Kalnik; Ko-Kopaonik; Md-Medvednica; SG-Samoborska gora and Mts. Žumberak; SD-Szarvaskö-Darnó; Bü-Bükk; JK-Jaklovce. The arrow indicates Mt. Kalnik (b) Sketch map of the structural units and major lineaments (modified after HAAS et al., 2000). Legend: 1- Austroalpine units; 2-Pelso Unit; 3-South Alpine units and Julian-Savinja and South Karawanken units; 4-South Zala Unit; 5-Central Slovenian and Bosnian units; 6-Medvednica Unit; 7-Kalnik Unit; 8-Internal Dinaridic Unit (Vardar Unit); 9-External Dinaridic Unit; 10-Tisza Mega-Unit; 11-black arrow indicates Mt. Kalnik study area; 12-box indicates the area shown on the Figure 2; BL-Balaton Lineament; ZZL-Zagreb-Zemplin Lineament; PL-Periadriatic Lineament.

calculated as the minimum concentration required to produce count rates three times higher than the square root of the background $(3 \mathrm{~s} ; 99 \mathrm{wt} . \%$ degree of confidence at the lowest detection limit). Natural minerals, oxides (corundum, spinel, hematite, and rutile), and silicates (albite, orthoclase, anorthite, and wollastonite) were used for calibration. The measurements relative error was less than $1 \%$. Raw data were corrected for matrix effects using the PAP algorithm (POUCHOU \& PICHOIR, 1984, 1985) implemented by CAMECA. Mineral phase formula calculations were done using a software package MINPET designed by Linda R. Richard.

Bulk-rock powders for chemical analyses of four samples were obtained from rock chips free of veins. The samples were analysed by ICP-OES for major elements and ICP-MS for all trace elements at Actlab Laboratories in Ancaster, Canada. International mafic rocks were used as standards. Major element and trace element concentrations were measured with accuracy better than $1 \%$ and $5 \%$, respectively.

\section{PETROGRAPHY AND MINERAL CHEMISTRY}

The investigated rocks in hand specimen are characterised by their black to dark green colour. They are massive and dense while breaking unevenly. Sporadically, the rocks may be mottled by the pale spots of plagioclase.
The texture of the analysed cumulate ultramafic rocks is granular allotriomorphic to poikilitic, while the structure is homogenous (Fig. 3), which is typical for the deepest part of an ophiolite sequence (e.g. MENZIES, 1973; ENGLAND \& DAVIES, 1973). These rocks are characterised by a network of cumulate crystals found in an immediate contact. The intercumulus space is filled by interstitial melt that has continued to produce minerals long after the previously crystallized phases have settled. This led to the development of a reaction series between mineral phases which defines a heteroadcumulate texture (WAGER et al., 1960; WAGER \& BROWN, 1968; IRVINE, 1982). Cumulate phases are spinel and olivine that are normally enclosed in intercumulus amphibole and/or plagioclase. Both intercumulus phases define an interstitial mesostasis (Fig. 3a-b). Spinel represents the earliest cumulate phase that is readily hemmed in by olivine (Fig. $3 \mathrm{~b}$ and 3d). Alternatively, both phases are marked by a cotectic growth (Fig. 3a and 3c). Orthopyroxene and clinopyroxene are rarely reported as cumuli, while more commonly they emerge along with the coarse oikocrystals of brown amphibole filling the intercumulus space and enclosing spinel and olivine (Fig. 3c-d). The last intercumulus crystallization phase is plagioclase that occurs as mesostasis in the interstitial space between clinopyroxene and orthopyroxene (Fig. 3b). Accessory phases are leucoxene and tiny apatite reported in intercumulus plagioclase. Such textural char- 


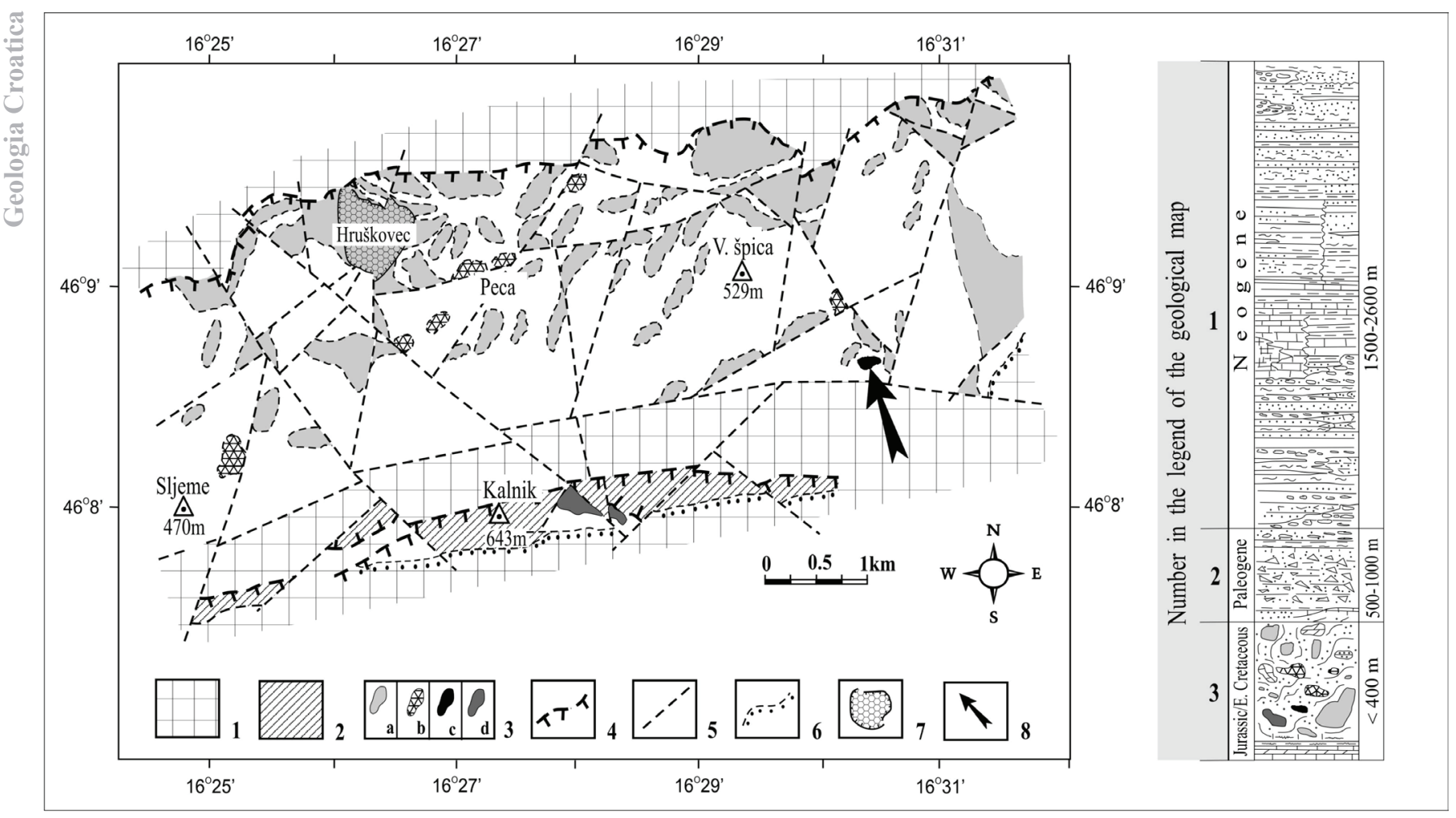

Figure 2. Simplified geological map and stratigraphic column of Mt. Kalnik (modified after ŠIMUNIĆ et al., 1982 and HALAMIĆ, 1998). Legend: 1-Neogene sedimentary rocks; 2-Palaeogene sedimentary rocks; 3-Jurassic/Early Cretaceous ophiolite mélange with blocks of: 3a-basalt, 3b-gabbro, 3c-tectonite peridotite/ amphibolite, 3d-ultramafic cumulates and Triassic-Jurassic radiolarites, sandstones and shales (not separated on the map); 4-reverse or thrust faults; 5-normal faults; 6-discordance line, tectonic-erosion discordance; 7-quarry; 8-black arrow indicates the blocks of ultramafic cumulates in the Mt. Kalnik ophiolite mélange.
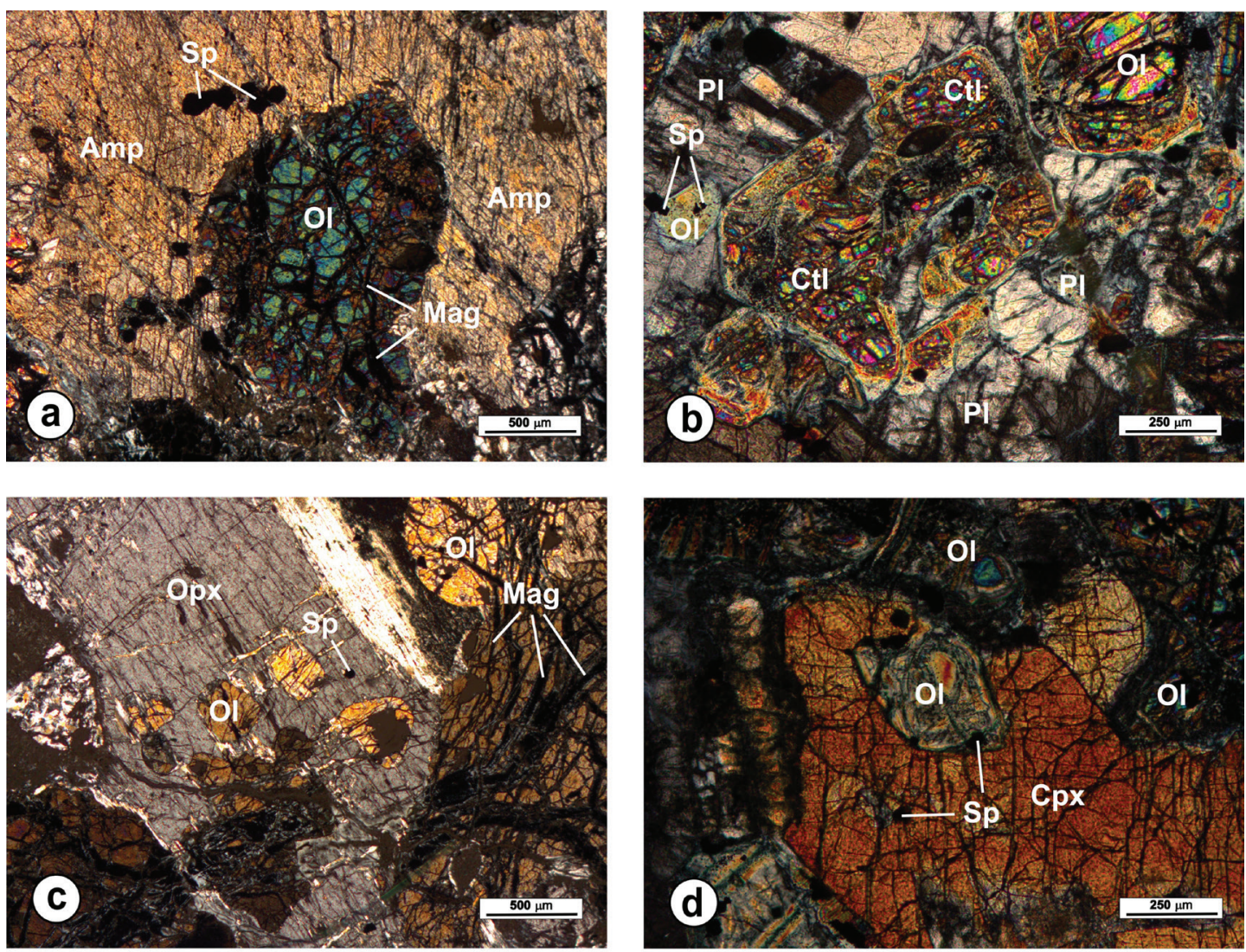

Figure 3. Photomicrographs of the Mt. Kalnik ultramafic cumulates thin sections obtained under polarized light: (a) Olivine and spinel enclosed in intercumulus amphibole (amphibole lherzolite), (b) Poikilitic plagioclase fill intercumulus space and cumulus olivine serpentinization in the mesh chrysotile (plagioclase lherzolite), (c) Olivine enclosed in intercumulus orthopyroxene (amphibole harzburgite) and (d) Spinel enclosed in olivine and as individual cumulii within the intercumulus clinopyroxene (amphibole Iherzolite). Legend: Amp - amphibole, Cpx - clinopyroxene, Ctl - chrysotile, Mag - magnetite, Ol - olivine, Opx - orthopyroxene, $\mathrm{Pl}$ - plagioclase, $\mathrm{Sp}$ - spinel. 


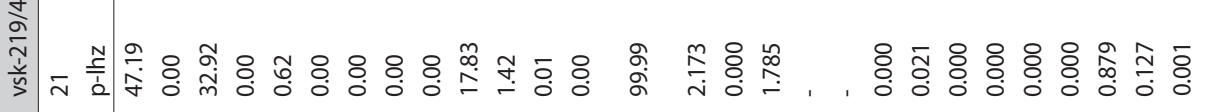

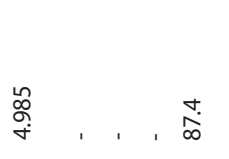

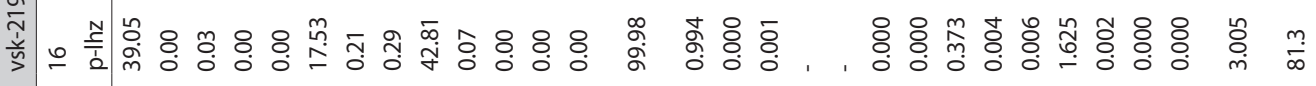

产 m

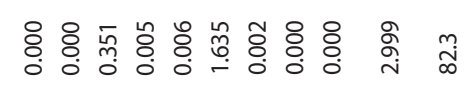

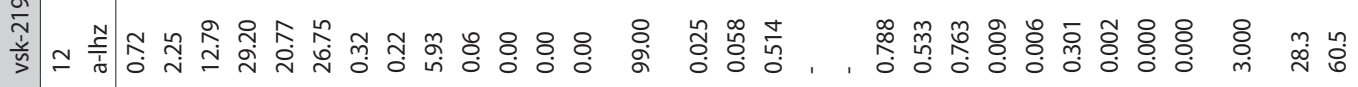


acteristics are commonly reported in ophiolites and may stand for the post-cumulus crystallization of an intercumulus melt (e.g. TRIBUZIO et al., 1995, 1999; ROSS \& ELTHON, 1997). The modal composition of analysed cumulate ultramafic rocks is as follows: olivine $\rightarrow 40-70 \%$, orthopyroxene $\rightarrow 5-25 \%$, clinopyrox- ene $\rightarrow 1-36 \%$, amphibole $\rightarrow 10-33 \%$, plagioclase $\rightarrow 0-2 \%$ and spinel" $0-0.6 \%$. Based on the abundances of identified mineral phases (STRECKEISEN, 1974), the poikilitic heteroadcumulate ultramafites of Mt. Kalnik are classified as amphibole lherzolite/harzburgite and, to a lesser extent, plagioclase lherzolite.

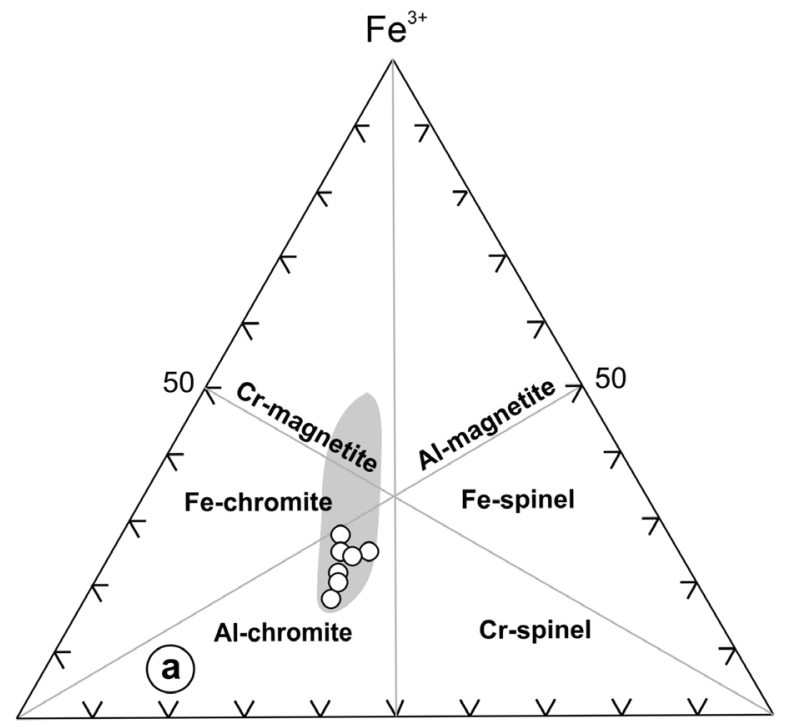

$\mathrm{Cr}$

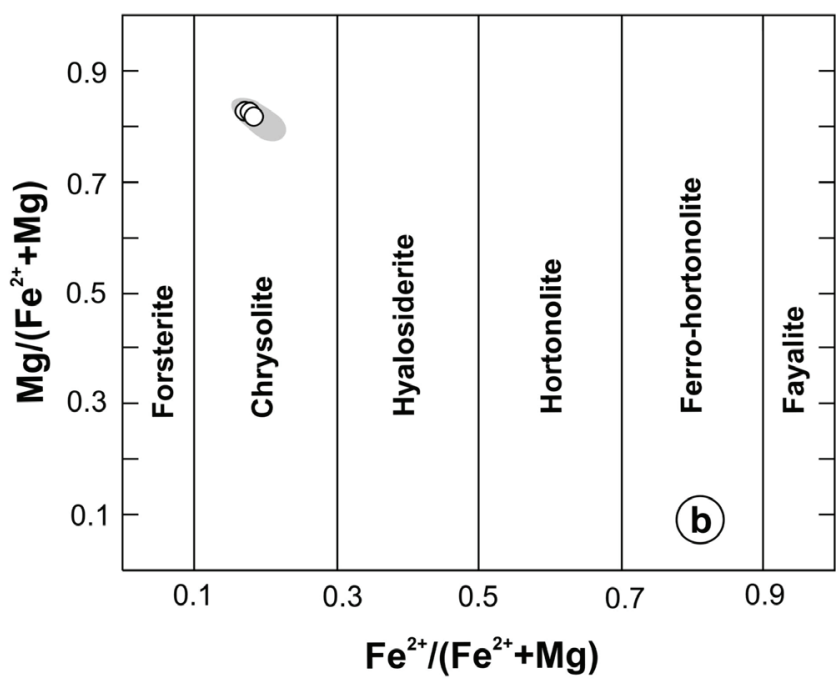

- Mesozoic ultramafic cumulates from Medvednica Mt.

$\mathrm{Ca}_{2} \mathrm{Si}_{2} \mathrm{O}_{6}(\mathrm{Wo})$

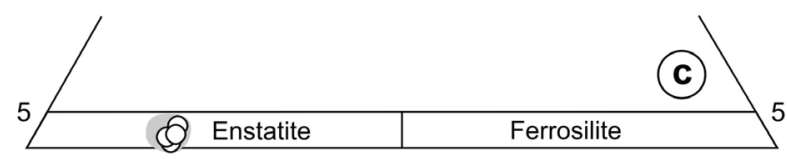

$\mathrm{Mg}_{2} \mathrm{Si}_{2} \mathrm{O}_{6}(\mathrm{En})$
$\mathrm{Fe}_{2} \mathrm{Si}_{2} \mathrm{O}_{6}(\mathrm{Fs})$

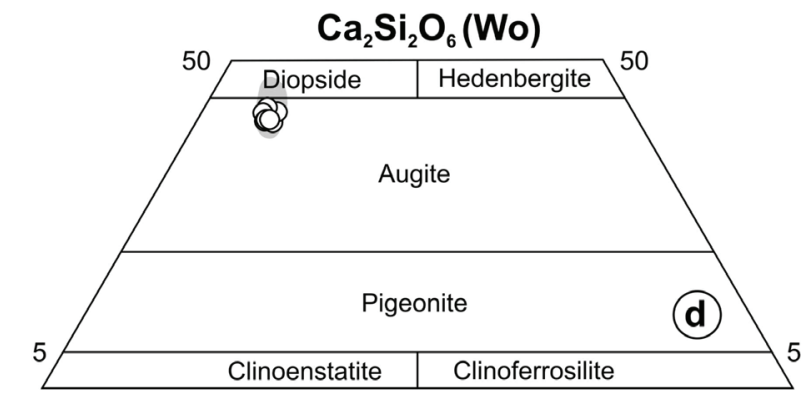

$\mathrm{Mg}_{2} \mathrm{Si}_{2} \mathrm{O}_{6}$ (En)

$\mathrm{Fe}_{2} \mathrm{Si}_{2} \mathrm{O}_{6}(\mathrm{Fs})$

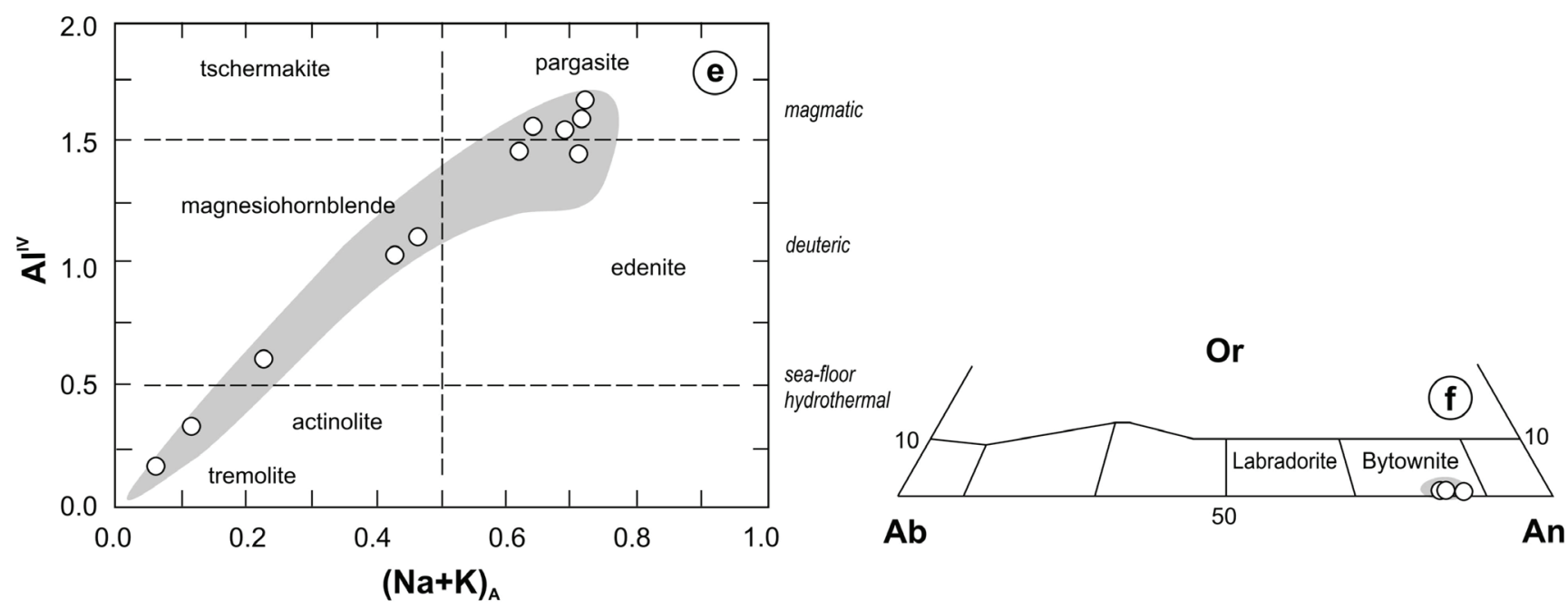

Figure 4. (a) Classification diagrams for (a) spinel (trivalent $\mathrm{Cr}-\mathrm{Al}-\mathrm{Fe}^{3+}$ ternary cation plot; STEVENS, 1944), (b) olivine (Fe ${ }^{2+} /\left(\mathrm{Fe}^{2+}+\mathrm{Mg}\right)-\mathrm{Mg} /\left(\mathrm{Fe}^{2+}+\mathrm{Mg}\right)$ ) cation plot; DEER et al., 1997), (c-d) pyroxene (En-Wo-Fs $\left(\mathrm{Mg}_{2} \mathrm{Si}_{2} \mathrm{O}_{6}-\mathrm{Ca}_{2} \mathrm{Si}_{2} \mathrm{O}_{6}-\mathrm{Fe}_{2} \mathrm{Si}_{2} \mathrm{O}_{6}\right)$ plot; MORIMOTO, 1988), (e) amphibole (AI ${ }^{\mathrm{IV}}-(\mathrm{Na}+\mathrm{K})_{\mathrm{A}}$ plot; adopted after LEAKE et al., 1997 and HAWTHORNE et al., 2012), (f) feldspar (Ab-An-Or plot; DEER et al., 1992) from the ultramafic cumulates from the Mt. Kalnik ophiolite mélange. Field for mineral compositions from Mesozoic ultramafic cumulates from Medvednica Mt. ophiolite mélange (LUGOVIĆ et al., 2007) plotted for correlation constraints. 
Primary mineral phases show different degrees of alterations. Olivine is partly serpentinized into reticular chrysotile (Fig. 3b). Within the olivine cracks one may often notice dispersed agglomerations of magnetite, which is yet another serpentinization product (Fig. 3a-c). Pyroxene is, along the rims, frequently uralitized or altered to chlorite, whereas plagioclase may be altered to saussurite or prehnite. Cumulate fine-grained spinel represents a cumulate phase representing virtually the only remaining fresh primary phase.

Phase chemistry of the analysed minerals is provided in Table 1. Spinel is subhedral (up to $0.3 \mathrm{~mm}$ in size) Al-chromite (Fig. 4a) of uniform chemical composition that features a somewhat elevated Ti content (1.55-2.25 wt\%), moderate range of $\mathrm{Fe}_{2} \mathrm{O}_{3}$ (13.01-20.77 wt\%), and relatively low Mg\# (28.3-38.1). The chromium number is relatively high (54.4-60.5) while $\mathrm{Fe}^{3+} \#$ is elevated (18.1-29.1), which is a consequence of an oxidizing environment. Subhedral to subrounded unzoned olivine (up to $1.5 \mathrm{~mm}$ in size) ranges in composition from $\mathrm{Fo}_{81}$ to $\mathrm{Fo}_{83}$ showing a chrysolite composition (Fig. 4b) due to its high $\mathrm{Mg \#} \mathrm{(81.3-82.3)} \mathrm{and} \mathrm{low}$ content of $\mathrm{CaO}(<0.08 \mathrm{wt} \%)$, while the content of $\mathrm{NiO}(0.28-0.29$ $\mathrm{wt} \%$ ) is characteristic for olivine from crustal peridotite (LEBLANC et al., 1984). Orthopyroxene (up to $3 \mathrm{~mm}$ in size) is enstatite $\left(\mathrm{Wo}_{1.1-3.4} \mathrm{En}_{78.4-80.2} \mathrm{Fs}_{18.1-18.8}\right.$; Fig. $\left.4 \mathrm{c}\right)$ with $\mathrm{Mg} \#$ values between 81.3-83.2 whereas the content of $\mathrm{Al}_{2} \mathrm{O}_{3}$ is relatively high (1.44-1.61 wt\%). Similar Mg\# of orthopyroxene and olivine reported in the portion of analysed rocks are presumably a result of their common formation as liquidus phases (Table 1). Clinopyroxene (up to $2.5 \mathrm{~mm}$ in size) has been classified as Mg-rich

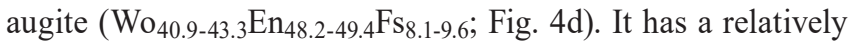
high $\mathrm{Mg} \#$ (87.1-89.6), moderately low content of $\mathrm{Al}_{2} \mathrm{O}_{3}(<2.68$ wt $\%)$, very low content of $\mathrm{TiO}_{2}(<0.55 \mathrm{wt} \%)$ and low values of $\mathrm{Al}^{\mathrm{VI}} / \mathrm{Al}^{\mathrm{IV}}$ ratio (0.10-0.40). Pale brown and poorly pleochroic igneous amphibole (up to $6.5 \mathrm{~mm}$ in size) corresponds to pargasite and edenite with $\mathrm{Mg \#}$ between 76.7 and 80.8. Compared to late magmatic magnesiohornblende and secondary actinolite and tremolite analysed amphibole has elevated values of $\mathrm{TiO}_{2}(0.54-$ $2.91 \mathrm{wt} \%), \mathrm{Al}_{2} \mathrm{O}_{3}(10.09-11.17 \mathrm{wt} \%), \mathrm{Na}_{2} \mathrm{O}(2.01-2.79 \mathrm{wt} \%)$ and
$\mathrm{K}_{2} \mathrm{O}(0.14-0.23 \mathrm{wt} \%$ ) (Fig. 4e; Table 1). Relict plagioclase (up to $2 \mathrm{~mm}$ in size) in metastasis shows a homogenous composition $\mathrm{An}_{82.6-87.4}$ (Fig. 4f; Table 1).

\section{BULK ROCK CHEMICAL COMPOSITION}

Chemical composition of the ultramafic cumulates from Mt. Kalnik is given in Table 2. The analysed rocks underwent a deuteric and sea-floor hydrothermal alteration which led to an increase in the loss on ignition ( $\mathrm{LOI} \leq 7.00 \mathrm{wt} \%$ ). However, the preserved magmatic texture and only minor chemical disturbances of the major element content do not exhibit an appreciable impact on the original rocks' chemistry. The ultramafic cumulate nature of the analysed rocks may be clearly inferred from the $\mathrm{CaO}-\mathrm{MgO}-$ $\mathrm{Al}_{2} \mathrm{O}_{3}$ classification diagram (Fig. 5a). They are characterised by low contents of $\mathrm{MgO}(\leq 25.16 \mathrm{wt} \%)$ and $\mathrm{TiO}_{2}(\leq 0.31 \mathrm{wt} \%)$, which defines the analysed cumulates as low Ti rocks (Fig. 5b). The contents of $\mathrm{Fe}_{2} \mathrm{O}_{3 \text { total }}$ and $\mathrm{Ni}$ are elevated (13.86-15.96 wt\% and 1121$1290 \mathrm{ppm}$, respectively), while the $\mathrm{Mg} \#$ is moderately high (75.378.4). A low content of $\mathrm{SiO}_{2}(37.06-40.63 \mathrm{wt} \%)$ is a typical feature of analysed intrusives suggesting their cumulate origin. Highfield strength elements (HFSE; Ti, P, Ta, Nb, Y and Th) as well as rare earth elements (REE) appeared to be relatively immobile during alteration. They maintained the typical igneous concentration levels and characteristic ratios (e.g. $\mathrm{Zr} / \mathrm{Hf}=41-44$; $\mathrm{Ti} / \mathrm{Zr}$ $=49-87 ; \mathrm{Nb} / \mathrm{Y}=0.02-0.03 ; \mathrm{Sm} / \mathrm{Nd}=0.3-0.4)$. Conversely, the large ion lithophile elements (LILE) showed a high degree of post-magmatic mobility and are therefore considered unsuitable for petrogenetic and geotectonic consideration.

The multi-element abundance patterns normalised to NMORB are displayed in Fig. 6a, while the chondrite-normalised REE patterns are given in Fig. 6b. All rocks display a LILE enrichment which is consistent with post-magmatic alterations. Normalised patterns for a range from $\mathrm{La}$ to $\mathrm{Lu}$ are flat being at 0.2 to 0.6 times relative to N-MORB. A very low content of incompatible elements in cumulate ultramafites may actually reflect their cumulate origin (SAUNDERS et al., 1980; MEYER et al., 1989). Additionally, all analysed samples possess pronounced

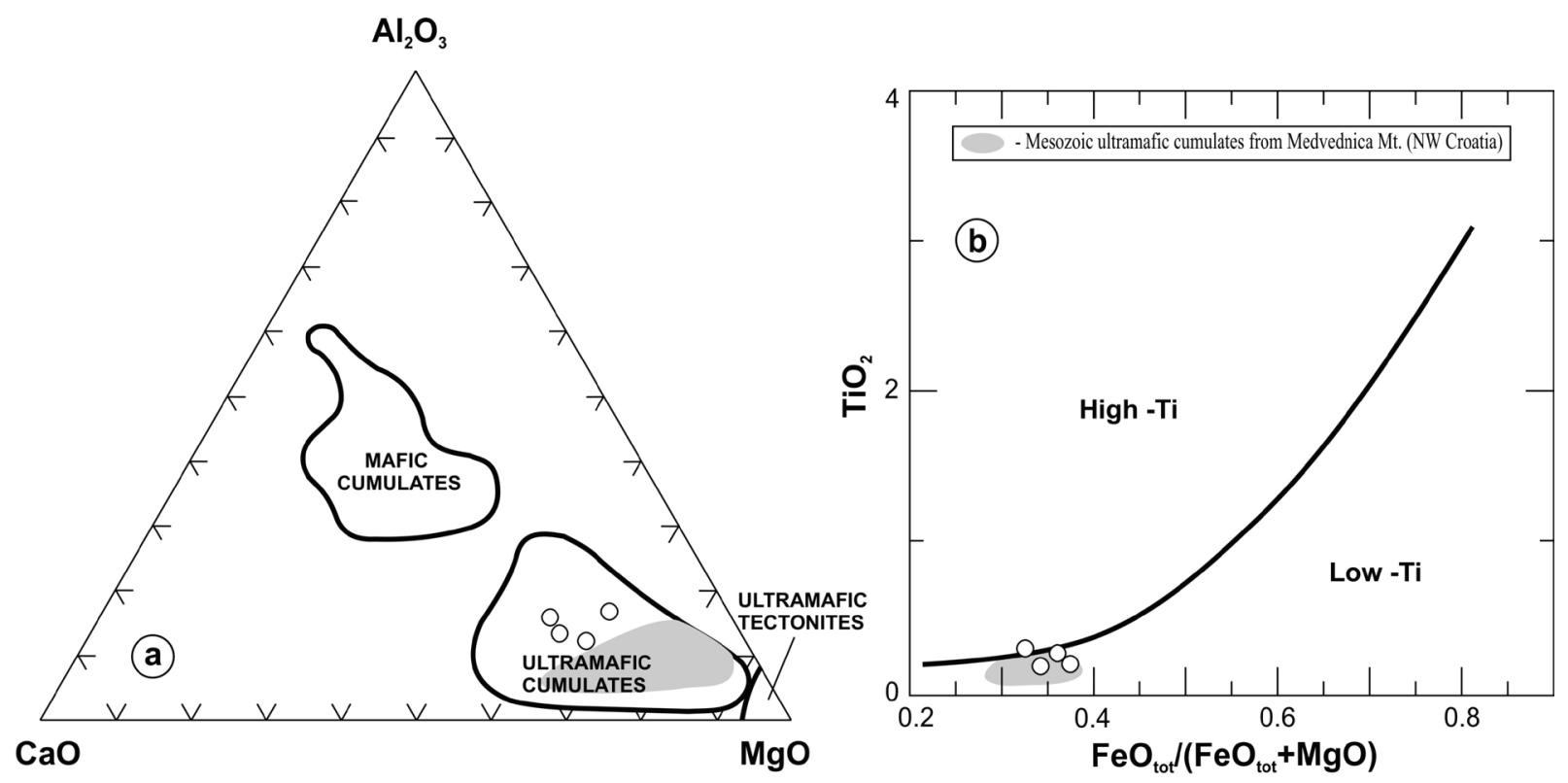

Figure 5. Discrimination diagrams for ultramafic cumulates from the Mt. Kalnik ophiolite mélange. (a) $\mathrm{CaO}_{-} \mathrm{MgO}-\mathrm{Al}_{2} \mathrm{O}_{3}$ diagram $(\mathrm{COLEMAN}, 1977) ;(\mathrm{b}) \mathrm{TiO}_{2}-\mathrm{FeO}_{\text {tot }} /$ $\left(\mathrm{FeO}_{\text {to }}+\mathrm{MgO}\right.$ ) diagram (SERRI, 1981). Field for Mesozoic ultramafic cumulates from Medvednica Mt. ophiolite mélange (LUGOVIĆ et al., 2007) plotted for correlation constraints. 


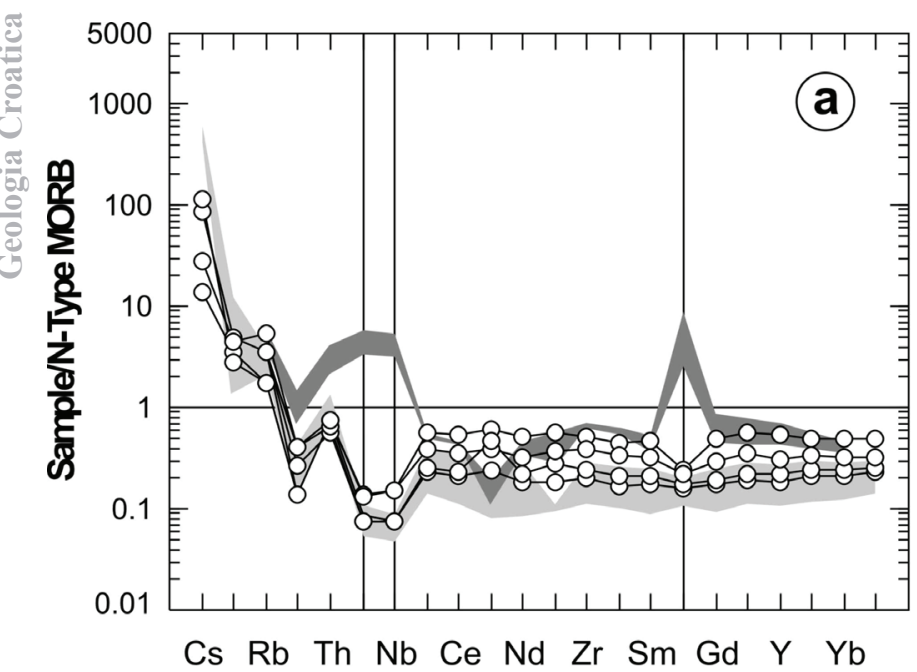

$\mathrm{Ba} \mathrm{K}$ Ta La Sr P $\mathrm{Hf}$ Ti Tb Tm Lu

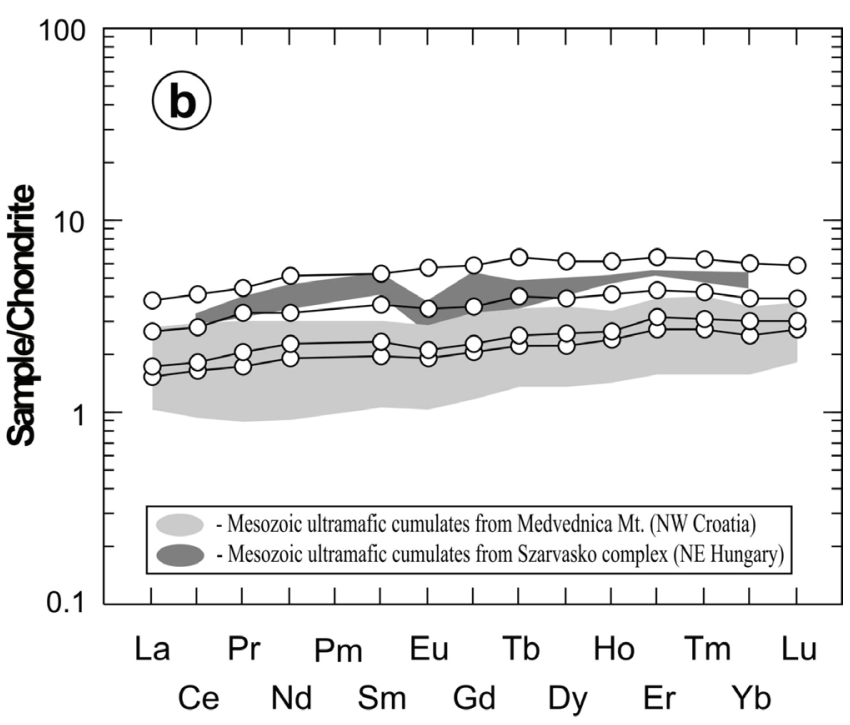

Figure 6. N-MORB-normalised multielement patterns (SUN \& MCDONOUGH, 1989); (b) REE-normalized patterns (TAYLOR \& MCLENNAN, 1985) for ultramafic cumulates from the Mt. Kalnik ophiolite mélange. Field for Mesozoic ultramafic cumulates from Medvednica Mt. ophiolite mélange (LUGOVIĆ et al., 2007) and from Szarvaskö complex (NE Hungary) (DOWNES et al., 1990; AIGNER-TORRES \& KOLLER, 1990) plotted for correlation constraints.

negative anomalies of the $\mathrm{Nb}-\mathrm{Ta}$ pair and $\mathrm{Ti}\left[(\mathrm{Nb} / \mathrm{La})_{\mathrm{n}}=0.25-\right.$ $\left.0.34 ;(\mathrm{Ti} / \mathrm{Gd})_{\mathrm{n}}=0.49-0.89\right]$. A positive anomaly of $\mathrm{Sr}$ in plagioclase lherzolite may be indicative of plagioclase fractionation. All analysed cumulates show similar chondrite-normalised REE patterns at different relative concentration levels. The REE patterns are characterised by nearly flat heavy rare earth elements (HREE) profiles $\left[(\mathrm{Tb} / \mathrm{Lu})_{\mathrm{cn}}=0.81-1.09\right]$ at 2.1-6.3 times relative to chondrite, whereas the light rare earth elements (LREE) are found to be slightly depleted compared to $\operatorname{HREE}\left[(\mathrm{La} / \mathrm{Lu})_{\mathrm{cn}}=0.57-0.68\right]$. Only plagioclase lherzolite shows a faint negative Eu anomaly $\left(\mathrm{Eu} / \mathrm{Eu}^{*}=0.92\right)$, which is typical for the minor accumulation of plagioclase. Relative depletion of LREE with regard to HREE defines a tholeiitic affinity of cumulate ultramafites from the ophiolite mélange of Mt. Kalnik (Fig. 6b).

\section{DISCUSSION AND CONCLUSIONS}

Fragments (i.e., blocks) of cumulate ultramafic rocks are the rarest member of the Mesozoic oceanic lithosphere documented in the ophiolitic mélange of Mt. Kalinik (Fig. 2). These metre-sized olistoliths originated from deep portions of oceanic crust and predominantly account for amphibole lherzolite and, to a lesser extent, amphibole harzburgite and plagioclase lherzolite. A lack of cumulate "layered" structures may suggest that the analysed rocks are not typical cumulates, and yet, the occurrence of heteroadcumulate texture visibly demonstrates the prevalence of cumulate processes at the time of formation of the Mt. Kalnik ophiolitic sequence. Cumulate ultramafites of Mt. Kalnik were formed in situ via crystallization in the magma chamber (CAMPBELL, 1978, 1987). Petrographic evidence suggests the following general crystallization order: Al-chromite $\rightarrow$ Mg-rich olivine (chrysolite) $\rightarrow$ enstatite \pm augite $\rightarrow$ Ca-amphibole (pargasite \pm edenite \pm magnesiohornblende) $\rightarrow$ Ca-plagioclase (bytownite) (Fig. 3). Spinel and olivine are the most common cumulate phases while the post-cumulate minerals are pyroxene, amphibole and plagioclase. Analysed rocks define a trend which is in accordance with the progressive removal of cumulate phases from the magma. Coarse oikocrysts of amphibole were formed from a magma that represents an intercumulus magmatic residuum. Amphibole frequently encloses other minerals. The crystallization of amphibole must have been sluggish thus enabling the development of several crystallization centres which ultimately gave rise to the formation of large poikilitic crystals of amphibole (Fig. 3a; WAGER \& BROWN, 1968).

Primary minerals' phase chemistry devoid of cryptic zoning clearly indicates that the analysed cumulate ultramafites were formed in an open crystallization system of a shallow magma chamber (e.g. ARISKIN \& YAROSHEVSKY, 2006; HOLNESS \& WINNPENY, 2009; LATYPOV, 2009). Mineral crystallization order along with the low $\mathrm{Al}^{\mathrm{VI}} / \mathrm{Al}^{\mathrm{IV}}(\leq 0.8)$ ratio in augite are typical characteristics of moderately low-pressure fractional crystallization (AOKI \& KUSHIRO, 1968; WASS, 1979; SERRI \& SAITTA, 1980; SHIFFMAN \& LOFGREN, 1982). Crystallization at moderately low pressures promoted an early separation of Ti oxides and hydrous silicates (i.e., chromite and pargasite/ edenite; PYTHON \& CEULENEER, 2003; LIU et al., 2010; KRAWCZYNSKI et al., 2012). This is in line with pressure values derived from augite composition (geobarometer after NIMIS \& ULMER, 1998; NIMIS, 1999), suggesting crystallization pressures between 0.6 and $0.9( \pm 0.2) \mathrm{GPa}$. In the graphic geothermometer of Lindsley (1983) analysed augite yielded maximum crystallization temperatures of between 950 and $1030( \pm 30)^{\circ} \mathrm{C}$, consistent with sub-solidus conditions. Mineralogical and textural characteristics of Mt. Kalnik poikilitic and heteroadcumulate peridotites discussed herein permit the inference that their primary mineral assemblage was formed through relatively fast crystallization (except oikocrysts of amphibole) and accumulation at subsolidus temperatures. The chemistry of olivine ( $\mathrm{Fo}_{82}$ ${ }_{79} ; \mathrm{CaO} \sim 0.07 \mathrm{wt} \%$ and $\mathrm{Ni} \sim 2278 \mathrm{ppm}$ ) is indicative of fractional crystallization of relatively primitive melts (e.g. STORMER, 1973; LARREA et al., 2014). The degree of fractionation was, however, relatively low $(\mathrm{La} / \mathrm{Yb}=0.9-1.0, \mathrm{Mg} \#=75.3-78.4)$ which suggests the process of partial melting as parental to the formation of a primitive melt that later yielded the magma to be fractionated and produce the Mt. Kalnik cumulates. JAQUES \& GREEN (1980) demonstrated that the first mineral phase formed after olivine in a cumulate sequence is determined by the degree of partial melting. In the investigated rocks the crystallization series olivine $\rightarrow$ orthopyroxene \pm clinopyroxene was established 

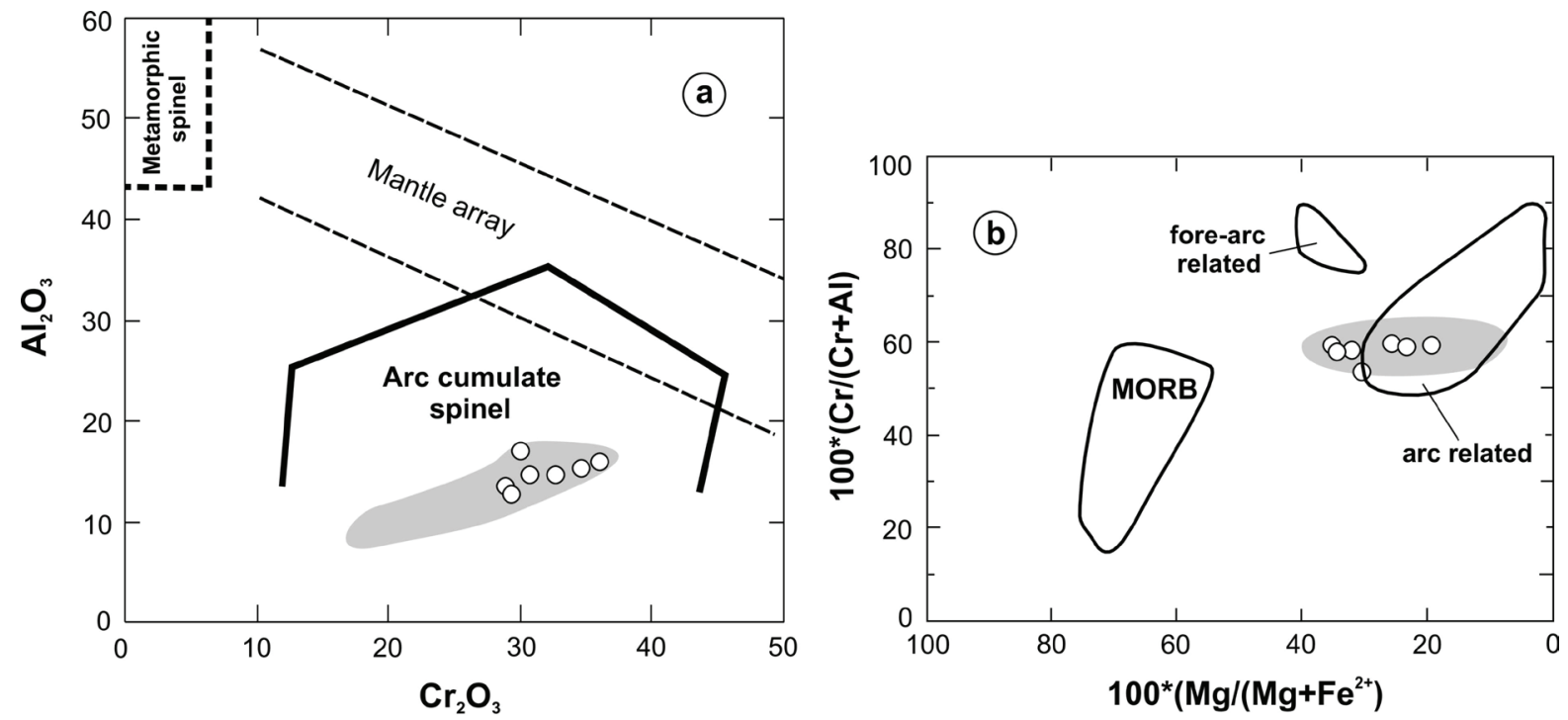

- Mesozoic ultramafic cumulates from Medvednica Mt

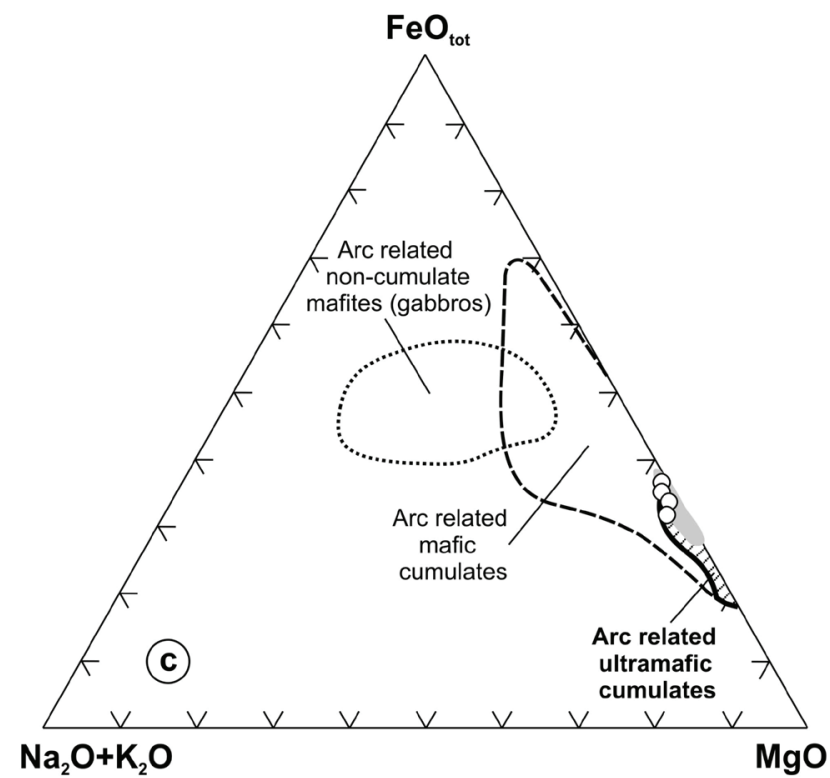

Figure 7. Discrimination diagrams for ultramafic cumulates from the Mt. Kalnik ophiolite mélange. (a) $\mathrm{Cr}_{2} \mathrm{O}_{3}-\mathrm{Al}_{2} \mathrm{O}_{3}$ diagram for spinels ( $\mathrm{FRANZ}$ \& WIRTH, 2000). (b) $100^{*}\left(\mathrm{Mg} /\left(\mathrm{Mg}+\mathrm{Fe}^{2+}\right)(\mathrm{Mg} \#)\right.$ vs. $100^{*}\left(\mathrm{Cr} /(\mathrm{Cr}+\mathrm{Al})(\mathrm{Cr} \#)\right.$ diagram for spinels. (c) $\mathrm{Na}_{2} \mathrm{O}+\mathrm{K}_{2} \mathrm{O}-\mathrm{MgO}^{-\mathrm{FeO}}$ tot diagram (BREAD, 1986). Data for MORB, fore-arc and arc related spinel fields are from KEPEZHINSKAS et al. (1993) and reference therein. Field for Mesozoic ultramafic cumulates from Medvednica Mt. ophiolite mélange (LUGOVIĆ et al., 2007) plotted for correlation constraints.

which according to JAQUES \& GREEN (1980) corresponds to medium to high degrees of partial melting of parental magma which leaves a mantle residue represented by harzburgite. A very low HFSE content ( 0.2 to 0.6 times relative to N-MORB) as well as a slight LREE depletion relative to HREE, along with a very low content of $\mathrm{Ti}$ in clinopyroxene indicate the origin of cumulates from a depleted source (PEARCE \& NORRY, 1979; BECCALUVA et al., 1989; Fig. 5b and Fig. 6).

Chemistry of amphibole reflects a relatively complex process of the formation of cumulate ultramafite from Mt. Kalnik. Namely, the amphibole is characterised by a peculiar compositional trend (i.e. "pargasitic trend", Fig. 4e), indicative of a multifold formation sequence that firstly includes the crystallization of the primary pargasitic phase. Further cooling under magmaticsubmagmatic conditions enhanced deuteric alteration of the pri- mary cumulate assemblage giving rise to the appearance of magnesiohornblende. Finally, post-magmatic processes related to sea-floor hydrothermal activity facilitated the formation of secondary actinolite/tremolite. The presence of hydrous primary amphibole (pargasite) in the studied rocks indicates crystallization of the ophiolite sequence from volatile-rich magmas characterised by a high oxidation potential. Such magmas are exclusively found in the intra-oceanic subduction zones, predominantly in island arcs, where hydrous mantle melting was facilitated by the addition of volatiles from the subducting slab (CONRAD \& KAY, 1984; DEBARI \& COLEMAN, 1989; TATSUMI \& EGGINS, 1995; KOEPKE \& SEIDEL, 2004; KOCAK et al., 2005). Formation of amphibole-rich ultramafic cumulates in arc settings has been studied well, both empirically and experimentally (e.g. LAROCQUE \& CANIL, 2010; KRAWCZYNSKI et 
Table 2. Chemical compositions of ultramafic cumulates in the Mt. Kalnik ophiolite mélange.

\begin{tabular}{|c|c|c|c|c|}
\hline Sample & vsk-219/1 & vsk-219/2 & vsk-219/3 & vsk-219/4 \\
\hline Rock type & $a-h z b$ & $\mathrm{a}-\mathrm{lhz}$ & $\mathrm{a}-\mathrm{lhz}$ & $\mathrm{p}-\mathrm{lhz}$ \\
\hline$\overline{\mathrm{SiO}_{2}}$ & 40.64 & 40.15 & 38.43 & 37.06 \\
\hline $\mathrm{TiO}_{2}$ & 0.31 & 0.20 & 0.29 & 0.22 \\
\hline $\mathrm{Al}_{2} \mathrm{O}_{3}$ & 6.15 & 5.85 & 4.96 & 7.21 \\
\hline $\mathrm{Fe}_{2} \mathrm{O}_{3 \text { total }}$ & 13.86 & 14.28 & 15.82 & 15.96 \\
\hline $\mathrm{MnO}$ & 0.16 & 0.11 & 0.14 & 0.18 \\
\hline $\mathrm{MgO}$ & 24.49 & 23.05 & 25.16 & 23.92 \\
\hline $\mathrm{CaO}$ & 6.26 & 10.61 & 9.79 & 11.51 \\
\hline $\mathrm{Na}_{2} \mathrm{O}$ & 0.90 & 0.28 & 0.46 & 0.33 \\
\hline $\mathrm{K}_{2} \mathrm{O}$ & 0.01 & 0.02 & 0.01 & 0.03 \\
\hline $\mathrm{P}_{2} \mathrm{O}_{5}$ & 0.06 & 0.02 & 0.04 & 0.03 \\
\hline LOI & 7.00 & 5.36 & 4.89 & 3.42 \\
\hline Total & 99.84 & 99.93 & 99.99 & 99.87 \\
\hline Mg\# & 78.4 & 77.3 & 76.2 & 75.3 \\
\hline Cs & 0.1 & 0.6 & 0.8 & 0.2 \\
\hline $\mathrm{Rb}$ & 1 & 2 & 1 & 3 \\
\hline $\mathrm{Ba}$ & 23 & 32 & 18 & 28 \\
\hline Th & 0.09 & 0.07 & 0.09 & 0.08 \\
\hline $\mathrm{Ta}$ & 0.02 & 0.01 & 0.02 & 0.01 \\
\hline $\mathrm{Nb}$ & 0.33 & 0.18 & 0.31 & 0.18 \\
\hline $\mathrm{Sr}$ & 45 & 22 & 33 & 35 \\
\hline $\mathrm{Zr}$ & 38 & 15 & 29 & 18 \\
\hline $\mathrm{Hf}$ & 0.92 & 0.34 & 0.69 & 0.43 \\
\hline Y & 15.1 & 5.2 & 8.9 & 6.3 \\
\hline Sc & 23 & 22 & 18 & 24 \\
\hline V & 125 & 129 & 121 & 131 \\
\hline $\mathrm{Cr}$ & 1800 & 1821 & 1932 & 1754 \\
\hline Co & 89 & 68 & 72 & 76 \\
\hline $\mathrm{Ni}$ & 1290 & 1260 & 1210 & 1121 \\
\hline La & 1.42 & 0.58 & 0.99 & 0.65 \\
\hline $\mathrm{Ce}$ & 4.05 & 1.63 & 2.71 & 1.79 \\
\hline $\operatorname{Pr}$ & 0.62 & 0.24 & 0.46 & 0.29 \\
\hline $\mathrm{Nd}$ & 3.74 & 1.38 & 2.41 & 1.65 \\
\hline Sm & 1.23 & 0.46 & 0.85 & 0.55 \\
\hline $\mathrm{Eu}$ & 0.521 & 0.172 & 0.311 & 0.188 \\
\hline $\mathrm{Gd}$ & 1.83 & 0.65 & 1.12 & 0.71 \\
\hline $\mathrm{Tb}$ & 0.38 & 0.13 & 0.24 & 0.15 \\
\hline Dy & 2.41 & 0.87 & 1.51 & 1.01 \\
\hline $\mathrm{Ho}$ & 0.53 & 0.21 & 0.36 & 0.23 \\
\hline Er & 1.62 & 0.68 & 1.10 & 0.79 \\
\hline $\mathrm{Tm}$ & 0.228 & 0.099 & 0.155 & 0.110 \\
\hline $\mathrm{Yb}$ & 1.52 & 0.64 & 0.99 & 0.76 \\
\hline Lu & 0.229 & 0.106 & 0.151 & 0.115 \\
\hline
\end{tabular}

Major elements in wt.\%, trace elements in ppm.

$\mathrm{LOI}=$ loss on ignition at $1100^{\circ} \mathrm{C}$.

$\mathrm{lhz}=$ lherzolite, $\mathrm{hzb}=$ harzburgite;

a-, p- = amphibole- or plagioclase-bearing assemblage.

$\mathrm{Mg} \#=100 * \mathrm{molar}\left(\mathrm{MgO} /\left(\mathrm{MgO}+\mathrm{FeO}_{\text {total }}\right)\right)$.

al., 2012). Their occurrence is commonly linked to the middle to lower crust of volcanic arcs (DAVIDSON et al., 2007). Low content of $\mathrm{TiO}_{2}(\leq 0.54 \mathrm{wt} \%)$ in augite and the presence of Ca-rich plagioclase is yet another characteristic of magmatic arc (e.g. BEARD, 1986; DEBARI \& COLEMAN, 1989; PARLAK et al., 1996; ILBEYLI, 2008) and forearc (BALLANTYNE, 1992) settings in which analysed cumulates could have probably originated during the Upper Jurassic. However, chromite is still considered as a most reliable indicator of the geotectonic affiliation of intrusive parts of a cumulate sequence (e.g. KAMENETSKY et al., 2001). Chemistry of Al-chromite thus strongly suggests that analysed cumulates originated in an island-arc setting making a clear distinction from a possible forearc geotectonic setting (Fig. $7 \mathrm{a}-\mathrm{b})$. This line of reasoning is further corroborated by cumulates' major element content $\left(\mathrm{Na}_{2} \mathrm{O}+\mathrm{K}_{2} \mathrm{O}-\mathrm{MgO}-\mathrm{FeO}\right.$ tot diagram; Fig. 7c), along with the negative $\mathrm{Ta}-\mathrm{Nb}$ pair and $\mathrm{Ti}$ anomalies and relatively uniform depletion of HFSE and REE in multi-elemental plots normalised to N-MORB (Fig. 6a). These features are typical for suprasubduction zone (SSZ) magmas and therefore clearly indicate the influence of the subduction component.

Taking into account that Mesozoic (probably Upper Jurassic) ultramafite cumulates are rarely encountered in the ophiolite complexes/mélanges of the ZMTDZ there is a paucity of correlative mineralogical, petrologic and geochemical data. In addition to ultramafic olistoliths from the ophiolitic mélange of Mts. Kalnik and Medvednica (LUGOVIĆ et al., 2007), similar ultramafic lithotypes were reported at the north-easternmost part of the ZMTDZ in the Szarvaskö magmatic complex (Mts. Bükk) in Hungary (BALLA et al., 1983; BALLA, 1984; KUBOVICS, 1984; KUBOVICS \& BILIK, 1984; DOWNES et al., 1990; HARANGI et al., 1996; JÓZSA, 1999; AIGNER-TORRES \& KOLLER, 1999; Fig. 1a-b). Common characteristics of ultramafite cumulates from the three ophiolite complexes/mélanges is the presence of igneous intercumulus oikocrysts of amphibole, an early crystallization of Ti rich non-silicate minerals, low-grade (prehnite-pumpellyite facies) alteration overprint that took place during the Alpine orogeny and under a rather high oxidation state. The sequence of crystallization and mineral phase chemistry as well as rock bulk chemistry is very similar when comparing the cumulate lithotypes from the ophiolite mélange of Mts. Kalnik and Medvednica (Fig. 4). In general, ultramafic cumulates from all three localities within the ZMTDZ show similar normalised concentration patterns at different fractionation levels (Fig. 6), which point to a common origin but different degrees of evolution of the parental magma. Nonetheless, the absence of the negative $\mathrm{Ta}-\mathrm{Nb}$ pair and $\mathrm{Ti}$ anomalies in ultramafites from the Szarvaskö complex and fractionation from an evolved basic melt distinguish these rocks (wherlite) from the cumulates of Mts. Kalnik and Medvednica whose geochemical particularities clearly testify to their formation in a supra-subduction arc setting (Fig. 6 and 7). Considering the discussion presented herein and previous literature on the fragments of oceanic lithosphere from the ophiolite mélange of Mts. Kalnik and Medvednica (LUGOVIĆ et al., 2007; SLOVENEC \& LUGOVIĆ, 2008; SLOVENEC et al., 2011; LUGOVIĆ et al., 2015) we suggest that ultramafic cumulates of the SW segment of the ZMTDZ originated from a single Mesozoic (most probably Upper Jurassic) oceanic domain. Subsequently, these rocks formed part of an intra-oceanic arc system formed in the western branch of the Meliata-Maliak segment of the Tethyan oceanic realm. Such a geodynamic scenario conforms well to the geotectonic reconstruction suggested by STAMPFLI \& BOREL $(2002,2004)$.

\section{ACKNOWLEDGEMENT}

This work contributes to the scientific project "Mesozoic magmatic, mantle and pyroclastic rocks of north-western Croatia (grant no. 181-1951126-1141 to Da. S.)" carried out under the support of the Croatian Ministry of Science, Education and Sport. We thank B. LUGOVIĆ and H-P. MEYER for microprobe facilities and I. FIN for excellent polished thin sections. Finally, the critical comments and constructive reviews by M. PUTIŠ and an anonymous reviewer contributed significantly to the quality of this paper. 


\section{REFERENCES}

AIGNER-TORRES, M. \& KOLLER, F. (1999): Nature of the magma source of the Szarvaskö complex (NE Hungary): petrological and geochemical constraints.Ofioliti, 24, 1-12.

ARISKIN, A.A. \& YAROSHEVSKY, A.A. (2006): Crystallization differentiation of intrusive magmatic melt: Development of a convection- accumulation model.- Geochemistry International, 44, 72-93. doi: 10.1134/S0016702906010083

AOKI, K. \& KUSHIRO, I. (1968): Some clinopyroxenes from ultramafic inclusions in Dreiser Weiher, Eifel.- Contr. Mineral. Petrol., 21, 743-749. doi: 10.1007/ BF00399694

BABIĆ, LJ., HOCHULI, P.A. \& ZUPANIČ, J. (2002): The Jurassic ophiolitic mélange in the NE Dinarides: Dating, internal structure and geotectonic implications.Eclogae Geologicae Helvetiae, 95, 263-257.

BAGCI, U. (2013): The geochemistry and petrology of the ophiolitic rocks from the Kahramanmaras region southern Turkey.- Turkish J. Earth Sci., 22, 536-562. doi: 10.3906/year-1203-1.

BALLA, Z. (1984): The North Hungarian Mesozoic mafics and ultramafics.-Acta Geol. Hung., 27, 341-357.

BALLA, Z., HOVORKA, D., KUZMIN, M. \& VINOGRADOV, V. (1983): Mesozoic ophiolites of the Bükk Mountains (North Hungary).- Ofioliti, 8, 5-45.

BALLANTYNE, P. (1992): Petrology and geochemistry of the plutonic rocks of the Halmahera ophiolite, eastern Indonesia, an analogue of modern oceanic forearcs.- In: L.M. PARSON, B.J. MURTON \& P. BROWNING (eds.): Ophiolites and their modern oceanic analogues.- Geol. Soc. Spec. Publ., 60, 179-202. doi: 10.1144/ GSL.SP.1992.060.01.11

BECCALUVA, L., MACCIOTTA, G., PICCARDO, G.B. \& ZEDA, O. (1989): Clinopyroxene composition of ophiolite basalts as petrogenetic indicator-- Chemical Geology, 77, 165-182. doi: 10.1016/0009-2541(89)90073-9

BORTOLOTTI, V. \& PRINCIPI, G. (2005): Tethyan ophiolites and Pangea break-up.Island Arc, 14, 442-470. doi: 10.1111/j.1440-1738.2005.00478.x

BORTOLOTTI, V., CHIARI, M., MARRONI, M., PANDOLFI, L., PRINCIPI, G., SACCANI, E. (2013): The geodynamic evolution of the ophiolites from Albania and Greece, Dinaric-Hellenic Belt: one, two, or more oceanic basins?- Int. J. Earth Sci., 102, 783-811. doi: 10.1007/s00531-012-0835-7.

BREAD, J.S. (1986): Characteristic mineralogy of arc-related cumulate gabbros: implications for the tectonic setting of gabbroic plutons and for andesite genesis.- Geology, 14, 848-851. doi: 10.1130/0091-7613(1986)14\%3C848:CMOACG\%3E2. $0 . \mathrm{CO} ; 2$

CAMPBELL, I.H. (1978): Some problems with the cumulus theory.- Lithos, 11, 311323. doi: 10.1016/0024-4937(78)90038-5

CAMPBELL, I.H. (1987): Distribution of orthocumulate textures in the imberlana Intrusion.- J. Geol., 95, 35-54.

COLEMAN, R.G. (1977): Ophiolites. Springer-Verlag, Berlin, 229 p. doi: 10.1007/9783-642-66673-5

COLEMAN, R.G. (1981): Tectonic setting for ophiolite obduction in Oman.- J. Geophys. Res., 86, 2497-2508. doi: 10.1029/JB086iB04p02497

CONRAD, W.K. \& KAY, R.W. (1984): Ultramafic and mafic inclusions from Adak Islands: Crystallization history, and implications for the nature of primary magmas and crustal evolution in the Aleutian arc.- J. Petrol., 25, 88-125. doi: 10.1093/petrology/25.1.88

CRNKOVIĆ, B., BABIĆ, V. \& TOMAŠIĆ, I. (1974): The gabbro of Hruškovec near Ljubeščica on mount Kalnik (Northern Croatia).- Geološki vjesnik, 27, 153-171 (in Croatian with English summary).

DAVIDSON, J., TURNER, S., HANDLEY, H., MACPHERSON, C. \& DOSSETO, A., (2007): Amphibole "sponge" in arc crust?- Geology, 35, 787-790.

DEBARI, S.M. \& COLEMAN, R.G. (1989): Examination of deep levels of an island arc: Evidence from the Tonsina ultramafic-mafic assemblage, Tonsina, Alaska.- J. Geophys. Res., 94, 4373-4391. doi: 10.1029/JB094iB04p04373

DEER, W.A., HOWIE, R.A. \& ZUSSMAN, J. (1992): An introduction to the Rock forming Minerals, $2^{\text {nd }}$ ed., Harlow, Longman, 696 p.

DEER, W.A., HOWIE, R.A. \& ZUSSMAN, J. (1997): Rock-Forming Minerals; Vol. 1b. Alden Press, Osney, Mead, Oxford, 629 p.

DILEK, Y. (2003): Ophiolite pulses, mantle plumes and orogeny.- Geol. Soc. Lond. Spec. Publ., 218, 9-19. doi: 10.1144/GSL.SP.2003.218.01.02.

DILEK, Y. \& FURNES, H. (2011): Ophiolite genesis and global tectonics: Geochemical and tectonic fingerprinting of ancient oceanic lithosphere.- Geol. Soc. Am. Bull., $123,387-411$.

DILEK, Y. \& FURNES, H. (2014): Ophiolites and their origins.- Elements, 10, 93-100. doi: 10.2113/gselements.10.2.93

DOWNES, H., PANTÓ, G.Y., ÁRKAI, P. \& THIRLWALL, M.F. (1990): Petrology and geochemistry of Mesozoic igneous rock, Bükk Mountains.- Lithos, 24, 201-215. doi: 10.1016/0024-4937(90)90032-V

ENGLAND, R.N. \& DAVIES, H.L. (1973): Mineralogy of ultramafic cumulates and tectonites from eastern Papua.- Earth Planet. Lett., 17, 416-425. doi: 10.1016/0012$821 X(73) 90210-0$
FARYAD, S.W., SPIŠIAK, J., HORVÁT, P., HOVORKA, D., DIANIŠKA, I. \& JÓZSA, S. (2005): Petrological and geochemical features of the Meliata mafic rocks from the sutured Triassic oceanic basin, Western Carpathians.- Ofioliti, 30, 27-35.

FESTA, A., PINI, G.A., DILEK, Y. \& CODEGONE, J. (2010): Mélanges and mélangeforming processes: a historical overview and new concepts.- In: DILEK, Y. (ed.): Alpine Concept in Geology. International Geology Review, 52, 1040-1105.

FRANZ, L. \& WIRTH, R. (2000): Spinel inclusions in olivine of peridotite xenoliths from TUBAF seamount (Bismarck Archipelago/Papua New Guinea): evidence for the thermal and tectonic evolution of the oceanic lithosphere.- Contrib. Mineral. Petrol., 140, 283-295. doi: 10.1007/s004100000188

HAAS, J., MIOČ, P., PAMIĆ, J., TOMLJENOVIĆ, B., ÁRKAI, P., BÉRCZI-MAKK, A., KOROKNAI, B., KOVÁCS, S. \& R-FELGENHAUER, E. (2000): Complex structural pattern of the Alpine-Dinaridic Pannonian triple junction.- Int. J. Earth Sci., 89, 377-389. doi: 10.1007/s005310000093

HAAS, J. \& KOVÁCS, S. (2001): The Dinaridic-Alpine connection - as seen from Hungary.-Acta Geol. Hung., 44, 345-362.

HALAMIĆ, J. (1998): Lithostratigraphy of Jurassic and Cretaceous sediments with ophiolites from the Mts. Medvednica, Kalnik and Ivanščica.- PhD Thesis, University of Zagreb, Zagreb, 188 p. (in Croatian with English summary).

HARANGI, SZ., SZABÓ, CS., JÓZSA, S., SZOLDÁN, ZS., ÁRVA-SÓS, E., BALLA, M. \& KUBOVICS, I. (1996): Mesozoic igneous suites in Hungary: Implications for genesis and tectonic setting in the northwestern part of Tethys.-Int. Geol. Rev., 38, 336-360. doi: 10.1080/00206819709465339

HAWTHORNE, F.C., OBERTI, R., HARLOW, G.E., MARESCH, W.V., MARTIN, R.F., SCHUMACHER, J.C. \& WELCH, M.D. (2012): Nomenclature of the amphibole supergroup.-American Mineralogist, 9, 2031-2048. doi: 10.2138/am.2012.4276

HOECK, V., IONESCU, C. \& KOLLER, F. (2006): Mesozoic ophiolites in the Dinarides and the Carpathians: a review.-Acta Mineralogica-Petrographica, Abstract Series, $5,39-41$.

HOLNESS, M.B. \& WINPENNY, B. (2009): The Unit 12 allivalite, Eastern Layered Intrusion, Isle of Rum: a textural and geochemical study of an open-system magma chamber-- Geol. Mag., 146, 437-450. doi:10.1017/S0016756808005797.

HOVORKA, D., JAROŠ, J., KRATOCHVÍL, M., REICHWALDER, P., ROJKOVIČ, I., SPIŠIAK, J. \& TURANOVÁ, L. (1985): Ultramafic rocks of the Western Carpathians, Czechoslovakia.- Geol. Inst. Dionýz Štúr, Bratislava, 1-258.

HUOT, F. \& MAURY, R.C. (2002): The Round Mountain serpentinite mélange, northern Coast Ranges of California: An association of backarc and arc-related tectonic units.- GSA Bull., 114, 109-123.

ILBELY, N. (2008): Geochemical comparison of Ultramafic-mafic cumulate rocks from the Central Anatolian ophiolites, Turkey.- Int. Geol. Rev., 50, 810-825. doi: 10.2747/0020-6814.50.9.810

IRVINE, T.N. (1982): Terminology for layered intrusions.- J. Petrol., 23, 127-162. doi: 10.1093/petrology/23.2.127-a

IVAN, P. (2002): Relicts of the Meliata ocean crust: geodynamic implications of mineralogical, petrological and geochemical proxies.- Geol. Carpathica, 53, 245-256.

JAQUES, A. \& GREEN, D.H. (1980): Anhydrous melting of peridotite at 0-15 kb pressure and the genesis of tholeiitic basalts.-Contrib. Mineral. Petrol., 73, 287-310. doi: 10.1007/BF00381447

JÓZSA, S. (1999): Petrological and geochemical study of the Darnó Hill ocean floor magmatic rocks.- PhD Thesis, ELTE, Budapest, 173 p. (in Hungarian with English summary).

KAMENETSKY, V.S., CRAWFORD, A.J. \& MEFFRE, S. (2001): Factors controlling chemistry of magmatic spinel: an empirical study of associated olivine, $\mathrm{Cr}$-spinel and melt inclusions from primitive rocks.- J. Petrology, 42, 655-671. doi: 10.1093/ petrology/42.4.655

KEPEZHINSKAS, P.K., TAYLOR, R.N. \& TANAKA, H. (1993): Geochemistry of plutonic spinels from the North Kamchatka Arc: comparison with spinels from other tectonic settings.- Mineral. Mag., 57, 575-589. doi: 10.1180/minmag.1993.057.389.02

KISS, G., MOLNÁR, F., PALINKAŠ, L., KOVÁCS, S. \& HRVATOVIĆ, H. (2012): Correlation of Triassic advanced rifting-related Neotethyan submarine basaltic volcanism of the Darnó Unit (NE-Hungary) with some Dinaridic and Hellenidic occurrences on the basis of volcanological, fluid-rock interaction, and geochemical characteristics.- Int. J. Earth Sci., 101, 1503-1521.

KOCAK, K., ISIK, F., ARSLAN, M. \& ZEDEF, V. (2005): Petrological and source region characteristics of ophiolitic hornblende gabbros from the Aksarav and Kavseri regions, central Anatolian crystalline complex, Turkey.- J. Asian Earth Sci., 25, 883-891.

KOEPKE, J. \& SEIDEL, E. (2004): Hornblendites within ophiolites of Crete, Greece: evidence for amphibole-rich cumulates derived from an iron-rich tholeiitic melt.Ofioliti, 29, 159-175.

KRAWCZYNSKI, M., GROVE, T. \& BEHRENS, H. (2012): Amphibole stability in primitive arc magmas: effects of temperature, $\mathrm{H} 2 \mathrm{O}$ content, and oxygen fugacity.Contrib. Mineral. Petrol., 164, 317-339. doi: 10.1007/s00410-012-0740-x

KUBOVICS, I. (1984): On the petrogenesis of the north Hungarian basic-ultrabasic magmatic rocks.- Acta Geol. Hung., 27, 163-189. 
KUBOVICS, I. \& BILIK, I. (1984): Comparative investigation of the Hungarian Mesozoic basic-ultrabasic and some ophiolitic magmatic rocks in the Alp-Carpathian chain.- Acta Geol. Hung., 27, 321-339.

LAROCQUE, J. \& CANIL, D. (2010): The role of amphibole in the evolution of arc magmas and crust: the case from the Jurassic Bonanza arc section, Vancouver Island, Canada.-Contrib. Mineral. Petrol., 159, 475-492. doi: 10.1007/s00410-0090436-z

LARREA, P., GALÉ, C., UBIDE, T., WIDOM, E., LAGO, M. \& FRANÇA, Z. (2014): Magmatic evolution of Graciosa (Azores, Portugal).- J. Petrol., 55, 2125-2154. doi:10.1093/petrology/egu052.

LATYPOV, R. (2009): Testing the validity of the petrological hypothesis "No phenocrysts, no post-emplacement differentiation".- J. Petrol., 50, 1047-1069. doi:10.1093/petrology/egp031.

LEAKE, B.E. et al. (1997): Nomenclature of amphiboles: Report of the Subcommittee on amphiboles of the International Mineralogical Association, Commission on New Minerals and Mineral Names.- Canadian Mineralogist, 35, 219-246.

LEBLANC, M., DUPUY, C. \& MERLET, C. (1984): Nickel content of olivine as a discriminatory factor between tectonite and cumulate peridotite in ophiolites.- Sci. Géol. Bull., 37, 131-135. doi: 10.3406/sgeol.1984.1659

LINDSLEY, D.H. (1983): Pyroxene thermometry.- Amer. Mineralogist, 68, 477-493.

LIU, C.Z., WU, F.Y., WILDE, S.A., YU, L.J. \& LI, J.L. (2010): Anorthitic plagioclase and pargasitic amphibole in mantle peridotites from the Yungbwa ophiolite (southwestern Tibetan Plateau) formed by hydrous melt metasomatism.- Lithos, 114, 413-422. doi: 10.1016/j.lithos.2009.10.008

LUGOVIĆ, B., ALTHERR, R., RACZEK, I., HOFMANN, A.W. \& MAJER, V. (1991): Geochemistry of peridotites and mafic igneous rocks from the Central Dinaric Ophiolite Belt, Yugoslavia.-Contrib. Mineral. Petrol., 106, 201-216. doi: 10.1007/ BF00306434

LUGOVIĆ, B., SLOVENEC, DA., HALAMIĆ, J. \& ALTHERR, R. (2007): Petrology, geochemistry and geotectonic affinity of the Mesozoic ultramafic rocks from the southwesternmost Mid-Transdanubian Zone in Croatia.- Geol. Carpathica, 58, $511-530$.

LUGOVIĆ, B., SLOVENEC, D., SCHUSTER, R., SCHWARZ, W.H. \& HORVAT, M. (2015): Petrology, geochemistry and tectono-magmatic affinity of gabbroic olistoliths from the ophiolite mélange in the NW Dinaric-Vardar ophiolite zone (Mts. Kalnik and Ivanščica, North Croatia).- Geol. Croatica, 68/1, 25-49. doi. org/10.4154/GC.2015.03.

MAJER, V. (1993): Ophiolite complex of the Banija and Pokuplje region in Croatia and Mt. Pastirevo in Nortwestern Bosnia.- Acta Geol. HAZU, 23, 39-84 (in Croatian with English summary).

MENZIES, M. (1973): Mineralogy and partial melt textures within an ultramafic-mafic body, Greece.- Contrib. Mineral. Petrol., 42, 273-285. doi: 10.1007/BF00372606

MEYER, P.S., DICK, J.B. \& THOMPSON, G. (1989): Cumulate gabbros from the Southwest Indian Ridge, $54^{\circ} \mathrm{S}-7^{\circ} 16^{\prime} \mathrm{E}$ : implications for magmatic processes at a slow spreading ridge.- Contrib. Mineral. Petrol., 103, 44-63.

MOORES, E.M. \& JACKSON, E.D. (1974): Ophiolites and oceanic crust.- Nature, 250, 136-139. doi: 10.1038/250136a0

MORIMOTO, N. (1988): Nomenclature of pyroxenes.- Schweiz. Mineral. Petrogr. Mitteil., 68, 95-111.

NIMIS, P. (1999): Clinopyroxene geobarometry of magmatic rocks. Part 2. Structural geobarometers for basic to acid, tholeiitic and mildly alkaline magmatic systems.Contrib. Mineral. Petrol., 135, 62-74. doi: 10.1007/s004100050498

NIMIS, P. \& ULMER, P. (1998): Clinopyroxene geobarometry of magmatic rocks part 1: An expanded structural geobarometer for anhydrous and hydrous, basic and ultrabasic systems.- Contrib. Mineral. Petrol., 133, 122-135.

PAMIĆ, J. (1997): The northwesternmost outcrops of the Dinaridic ophiolites: a case study of the Mt. Kalnik (North Croatia).- Acta Geol. Hung., 40, 37-56.

PAMIĆ, J. (2000): The Periadriatic-Sava-Vardar Suture Zone.- In: I. VLAHOVIĆ \& R. BIONDIĆ (eds.): $2^{\text {nd }}$ Croatian Geological Congress Proceedings. Institute of Geology, Zagreb, 333-337 (in Croatian with English summary).

PAMIĆ, J. (2002): The Sava-Vardar Zone of the Dinarides and Hellenides versus the Vardar ocean.- Eclogae Geologicae Helvetiae, 95, 99-113.

PAMIĆ, J. \& DESMONS, J. (1989): A complete ophiolite sequence in Rzav, area of Zlatibor and Varda ultramafic massifs, the Dinaride ophiolite zone.- Ofioliti, 14, $13-32$.

PAMIĆ, J. \& TOMLJENOVIĆ, B. (1998): Basic geological data on the Croatian part of the Mid-Transdanubian Zone as exemplified by Mt. Medvednica located along the Zagreb-Zemplen Fault Zone.- Acta Geol. Hung., 41, 389-400.

PAMIĆ, J., TOMLJENOVIĆ, B. \& BALEN, D. (2002): Geodynamic and petrogenetic evolution of Alpine ophiolites from the central and NW Dinarides: an overview.Lithos, 65, 113-142.

PARLAK, O., DELALOYE, M. \& BÍNGÖL, E. (1996): Mineral chemistry of ultramafic and mafic cumulates as an indicator of the arc-related origin of the Mersin ophiolite (southern Turkey).-- Geol. Rundsch., 85, 647-661.
PARLAK, O., HÖCK, V. \& DELALOYE, M. (2002): The suprasubduction zone PoznatiKersanti ophiolite, southern Turkey: evidence for high-pressure crystal fractionation of ultramafic cumulates.- Lithos, 65, 205-224.

PEARCE, J.A. (2008): Geochemical fingerprinting of oceanic basalts with applications to ophiolite classification and the search for Archean oceanic crust.- Lithos, 100, 14-48. doi:10.1016/j.lithos.2007.06.016.

PEARCE, J.A. \& NORRY, M.J. (1979): Petrogenetic Implications of Ti, Zr, Y, and Nb Variations in Volcanic Rocks.- Contrib. Mineral. Petrol., 69, 33-47. doi: 10.1007/ BF00375192

PEARCE, J.A. (2003): Subduction zone ophiolites. In Dilek, Y., and Newcomb, S., eds. Ophiolite concept and the evolution of geological thought.- Geol. Soc. Am. Spec. Pap., 373, 269-294.

PYTHON, M. \& CEULENEER, G. (2003): Nature and distribution of dykes and related melt migration structures in the mantle section of the Oman ophiolite.- Geochem., Geophys., Geosyst., 4., 1-34. doi: 10.1029/2002GC000354

POLJAK, J. (1942): A contribution to the knowledge of geology of the Mt. Kalnik.Vjestnik Hrvatskog Državnog Geoložkog Zavoda i Hrvatskog Državnog Geoložkog Muzeja, 1, 53-92 (in Croatian with German summary).

POUCHOU, J.L. \& PICHOIR, F. (1984): A new model for quantitative analyses. I. Application to the analysis of homogeneous samples.- La Recherche Aérospatiale, 3 , $13-38$.

POUCHOU, J.L. \& PICHOIR, F. (1985): "PAP" ( $\varphi-\rho-Z)$ correction procedure for improved quantitative microanalysis.- In: ARMSTRONG, J.T. (ed.): Microbeam Analysis, San Francisco, California, USA: San Francisco Press, 104-106.

RAYMOND, L.A. (1984): Classification of melanges. In: L.A. RAYMOND (ed.): Mélanges: Their nature, origin, and significance.- Geol. Soc. of Amer. Spec. Paper, 198, 7-20. doi: 10.1130/SPE198-p7

ROSS, K. \& ELTHON, D. (1997): Cumulus and postcumulus crystallization in the ocean crust: major- and trace-element geochemistry of leg 153 gabbroic rocks.- In: KARSON, J.A., CANNAT, M., MILLET, D.J. \& ELTHON, D. (eds.): Proceedings of the Ocean Drilling Program, Scientific Results, vol. 153. Ocean Drilling Program, College Station, Texas, 333-350.

SACCANI, E. \& TASSINARI, R. (2015): The role of MORB and SSZ magma-types in the formation of Jurassic ultramafic cumulates in the Mirdita ophiolites (Albania) as deduced from chromian spinel and olivine chemistry.- Ofioliti, 40, 37-56.

SACCANI, E., DILEK, Y. \& PHOTIADES, A. (2017): Time-Progressive mantle-melt evolution and magma production in a Tethyan marginal sea: A Case study of the Albanide-Hellenide ophiolites.- Lithosphere. doi:10.1130/L602.1.

SAUNDERS, A.D., TARNEY, J., MARSH, N.G. \& WOOD, D.A. (1980): Ophiolites as ocean crust or marginal basin crust: A geochemical approach.- In: PANAYIOTOU, J. (ed.): Ophiolites, Proc. int. Ophiolite Conf. Nicosia, Cyprus, 193-204.

SCHMID, S.M., BERNOULLI, D., FÜGENSCHUH, B., MATENCO, L., SCHEFFER, S., SCHUSTER, R., TISCHLER, M. \& USTASZEWSKI, K. (2008): The AlpineCarpathian-Dinaridic orogenic system: correlation and evolution of tectonic units.Swiss J. Geosci., 101, 139-183. doi: 10.1007/s00015-008-1247-3

ŠEGVIĆ, B., LUGOVIĆ, B., SLOVENEC, DA. \& MEYER, H.-P. (2016): Mineralogy, petrology and geochemistry of amphibolites from the Kalnik Mt. (Sava Unit, North Croatia): Implications for the evolution of north-westernmost part of the DinaricVardar branch of Mesozoic Tethys.- Ofioliti, 41, 35-58. doi: 10.4454/ofioliti. v4li1.441.

SERRI, G. \& SAITTA, M. (1980): Fractionation trends of gabbroic complexes from high-Ti and low-Ti ophiolites and from the crust of major oceanic basins: a comparison.- Ofioliti, 5, 241-264.

SERRI, S. (1981): The petrochemistry of ophiolitic gabbro-complexes: A key for classification of ophiolites to low-Ti and high-Ti types.- Earth Planet. Sci. Lett., 52, 203-212.

SHERVAIS, J.W. (2001): Birth, dead, and resurrection: The Life cycle of supra-subduction zone ophiolites.- Geochem. Geophys. Geosys. 2, 1010, 45 p. doi: $10.1029 / 2000 \mathrm{GC} 000080$.

SHIFFMAN, P. \& LOFGREN, G.E. (1982): Dynamic crystallization studies on the Grande Ronde pillow basalts, Central Washington.- J. Geol., 90, 49-78. doi: $10.1086 / 628651$

ŠIMUNIĆ, AN., PIKIJA, M., HEĆIMOVIĆ, I. \& ŠIMUNIĆ, AL. (1981): Osnovna geološka karta SFRJ 1:100000. Tumač za list Varaždin L33-69 [Basic Geological Map of SFRY 1:100000, Geology of the Varaždin sheet - in Croatian].- Institut za geološka istraživanja Zagreb, Savezni geološki zavod Beograd, 1-81.

ŠIMUNIĆ, AN., PIKIJA, M. \& HEĆIMOVIĆ, I. (1982): Osnovna geološka karta SFRJ 1:100000, list Varaždin L33-69 [Basic Geological Map of SFRY 1:100000. Varaždin sheet - in Croatian].- Institut za geološka istraživanja Zagreb, Savezni geološki zavod Beograd.

SLOVENEC, DA. \& LUGOVIĆ B. (2000): Ultramafic cumulate rocks from the Medvednica Mts. ophiolite complex (Northwestern Croatia).- In: VLAHOVIĆ, I. \& BIONDIĆ, R. (eds.): Proceedings of the $2^{\text {nd }}$ Croatian Geological Congress. Institute of Geology, Zagreb, 379-385 (in Croatian with English summary). 
SLOVENEC, DA. \& LUGOVIĆ, B. (2008): Amphibole gabbroic rocks from the Mt. Medvednica ophiolite mélange (NW Croatia): geochemistry and tectonic setting.Geol. Carpathica, 59, 277-293.

SLOVENEC, DA., LUGOVIĆ, B., MEYER, H-P. \& GARAPIĆ-ŠIFTAR, G. (2011): A tectono-magmatic correlation of basaltic rocks from ophiolite mélanges at the north-eastern tip of the Sava-Vardar suture Zone, Northern Croatia, constrained by geochemistry and petrology.- Ofioliti, 36, 77-100.

STAMPFLI, G.M. \& BOREL, G.D. (2002): A plate tectonic model for the Paleozoic and Mesozoic constrained by dynamic plate boundaries and restored synthetic ocean isochrons.- Earth Planet. Sci. Lett., 196, 17-33.

STAMPFLI, G.M. \& BOREL, G.D. (2004): The TRANSMED transects in space and time: constraints on the paleotectonic evolution of the Mediterranean domain.-In: CAVAZZA, W., ROURE, F., SPAKMAN, W., STAMPFLI, G.M. \& ZIEGLER, P.A. (eds.): The TRANSMED Atlas: the Mediterranean Region from crust to mantle. Heidelberg, Germany: Springer, 53-80. doi: 10.1007/978-3-642-18919-7 3

STEVENS, R.E. (1944): Composition of some chromites of the 255. Western Hemisphere.-Amer. Mineralogist, 29, 1-34.

STRECKEISEN, A.L. (1974): Classification and nomenclature of plutonic rocks. Recommendations of the IUGS subcommission on the systematics of igneous rocks.Geol. Rdsch., 63, 773-786.

STORMER, J.C. (1973): Calcium zoning in olivine and its relationship to silica activity and pressure.- Geochim. Cosmochim. Acta, 37, 1815-1821. doi: 10.1016/00167037(73)90144-0

SUN, S.S. \& MCDONOUGH, W.F. (1989): Chemical and isotopic systematics of oceanic basalts: implications for mantle composition and processes.- In: SAUNDERS, A.D. \& NORRY, M.J. (eds.): Magmatism in ocean basins.- Geol. Soc. London, Spec. Publ., 42, 313-345. doi: 10.1144/GSL.SP.1989.042.01.19

SUN, S.S. \& NESBITT, R.W. (1978): Petrogenesis of Archaean Ultrabasic and Basic Volcanics: Evidence From Rare Earth Elements.- Contrib. Mineral. Petrol., 65, 301-325. doi: 10.1007/BF00375516
TATSUMI, Y. \& EGGINS, S. (1995): Subduction zone magmatism.-- Cambridge, Massachusetts, USA, Blacwell, $221 \mathrm{p}$.

TAYLOR, S.R. \& McLENNAN, S.M. (1985): The continental crust: its composition and evolution. Blackwell, Oxford, 312 p.

TOMLJENOVIĆ, B., CSONTOS, L., MÁRTON, E. \& MÁRTON, P. (2008): Tectonic evolution of the northwestern Internal Dinarides as constrained by structures and rotation of Medvednica Mountains, North Croatia.- Geol. Soc. London, Spec. Publ., 298, 145-167. doi: 10.1144/SP298.8

TRIBUZIO, R., RICCARDI, M.P. \& OTTOLINI, L. (1995): Trace element redistribution in high temperature deformed gabbros from East Ligurian ophiolites (Northern Apennine, Italy): constraints on the origin of syndeformation fluids.- J. Metamorph. Geol., 13, 367-377. doi: 10.1111/j.1525-1314.1995.tb00226.x

TRIBUZIO, R., TIEPOLO, M., VANNUCCI, R. \& BOTTAZZI, P. (1999): Trace element distribution within the olivine-bearing gabbros from the Northern Apennine ophiolites (Italy): evidence for post-cumulus crystallization in MOR-type gabbroic rocks.-Contrib. Mineral. Petrol., 134, 123-133. doi: 10.1007/s004100050473

VRKLJAN, M. (1989): Eruptive rocks from Mt. Kalnik.- PhD Thesis, University of Zagreb, Zagreb, 94 p. (in Croatian with English summary).

VRKLJAN, M. \& GARAŠIĆ, V. (2004): Different geochemical signatures developed in some basic magmatic rocks of Mt. Kalnik (North Croatia).- Rudarsko-geološkonaftni zbornik, 16, 65-73.

WAGER, L.R., BROWN, G.M. \& WADSWORTH W.J. (1960): Types of igneous cumulate.- J. Petrol., 1, 73-85. doi: 10.1093/petrology/1.1.73

WAGER, L.R. \& BROWN, G.M. (1968): Layered igneous rocks. Oliver \& Boyd, Edinburgh and London, $588 \mathrm{p}$.

WAKABAYASHI, J. \& DILEK, Y. (2003): What constitutes "emplacement" of an ophiolite?: mechanisms relationship to subduction initiation and formation of metamorphic soles.- In: DILEK, Y. \& ROBINSON, P.T. (eds.): Ophiolites in Earth history.- Geol. Soc. London, Spec. Publ., 218, 427-447.

WASS, S.Y. (1979): Multiple origins of clinopyroxenes in alcalic basaltic rocks.- Lithos, $12,116-132$ 